Review

\title{
Current Status of Optical Systems for Measuring Lycopene Content in Fruits: Review
}

\author{
Marcos-Jesús Villaseñor-Aguilar ${ }^{1,2,3}$, José-Alfredo Padilla-Medina ${ }^{1}$, José-Enrique Botello-Álvarez ${ }^{1}$, \\ Micael-Gerardo Bravo-Sánchez ${ }^{1}{ }^{(\mathbb{D}}$, Juan Prado-Olivares ${ }^{1}{ }^{(\mathbb{D}}$, Alejandro Espinosa-Calderon ${ }^{1,4} \mathbb{B}^{\mathbb{B}}$ \\ and Alejandro-Israel Barranco-Gutiérrez $1,5, *$ (i)
}

\section{check for}

updates

Citation: Villaseñor-Aguilar, M.-J.; Padilla-Medina, J.-A.; Botello-Álvarez, J.-E.; Bravo-Sánchez, M.-G.; PradoOlivares, J.; Espinosa-Calderon, A.; Barranco-Gutiérrez, A.-I. Current Status of Optical Systems for Measuring Lycopene Content in Fruits: Review. Appl. Sci. 2021, 11, 9332. https://doi.org/10.3390/ app11199332

Academic Editor: Agata Górska

Received: 17 July 2021

Accepted: 24 September 2021

Published: 8 October 2021

Publisher's Note: MDPI stays neutral with regard to jurisdictional claims in published maps and institutional affiliations.

Copyright: (c) 2021 by the authors. Licensee MDPI, Basel, Switzerland. This article is an open access article distributed under the terms and conditions of the Creative Commons Attribution (CC BY) license (https:/ / creativecommons.org/licenses/by/ $4.0 /)$.
1 Doctorado en Ciencias de la Ingeniería, Tecnológico Nacional de México en Celaya, Celaya 38010, Mexico mvillasenor@upgto.edu.mx (M.-J.V.-A.); alfredo.padilla@itcelaya.edu.mx (J.-A.P.-M.); enrique.botello@itcelaya.edu.mx (J.-E.B.-Á.); gerardo.bravo@itcelaya.edu.mx (M.-G.B.-S.); juan.prado@itcelaya.edu.mx (J.P.-O.); alejandro.espinosa@crodecelaya.edu.mx (A.E.-C.)

2 Departamento de Ingeniería de Robótica y de Datos, Universidad Politécnica de Guanajuato, Cortazar 38496, Mexico

3 Facultad de Ingeniería, Universidad de Celaya, Celaya 38080, Mexico

CRODE, Tecnológico Nacional de México en Celaya, Celaya 38010, Mexico

5 Cátedras-CONACyT, García Cubas esq. Av. Tecnológico, Celaya 38010, Mexico

* Correspondence: israel.barranco@itcelaya.edu.mx

\begin{abstract}
Optical systems are used for analysing the internal composition and the external properties in food. The measurement of the lycopene content in fruits and vegetables is important because of its benefits to human health. Lycopene prevents cardiovascular diseases, cataracts, cancer, osteoporosis, male infertility, and peritonitis. Among the optical systems focused on the estimation and identification of lycopene molecule are high-performance liquid chromatography (HPLC), the colorimeter, infrared near NIR spectroscopy, UV-VIS spectroscopy, Raman spectroscopy, and the systems of multispectral imaging (MSI) and hyperspectral imaging (HSI). The main objective of this paper is to present a review of the current state of optical systems used to measure lycopene in fruits. It also reports important factors to be considered in order to improve the design and implementation of those optical systems. Finally, it was observed that measurements with HPLC and spectrophotometry present the best results but use toxic solvents and require specialized personnel for their use. Moreover, another widely used technique is colorimetry, which correlates the lycopene content using color descriptors, typically those of CIELAB. Likewise, it was identified that spectroscopic techniques and multispectral images are gaining importance because they are fast and non-invasive.
\end{abstract}

Keywords: lycopene; optical system; colorimeter; spectroscopy; images; HPLC

\section{Introduction}

Optical systems in the agriculture and food sector are efficient tools that allow the external quality and characteristics of the internal composition of fruits to be determined, such as the shape, colors, maturity, vitamins, and soluble solids [1-4]. The operation principle of these systems is to associate the variable of interest of the vegetable or fruit matrix with the optical properties, such as the reflectance, transmittance, absorbance, fluorescence, and emission, which can be analyzed and associated with the radiation of light on the sample [5].

The study of the optical properties of each piece of fruit or vegetable is complex because of their non-uniform surface. The relevance of the knowledge of the structure allows identification of how light travels through food. In Figure 1, the light behavior schema on fruit radiated by a light beam is shown. Chen [5] reported that approximately $4 \%$ of the radiation incident on the fruit surface is reflected, on the outside, in the regular form of reflectance. The rest of the radiation is transmitted in all directions through the surface and the tissue of the fruit formed by the cellular structure, and the transmitted 
energy can be absorbed or reach the other surface of the fruit with the same or a different wavelength [6,7].

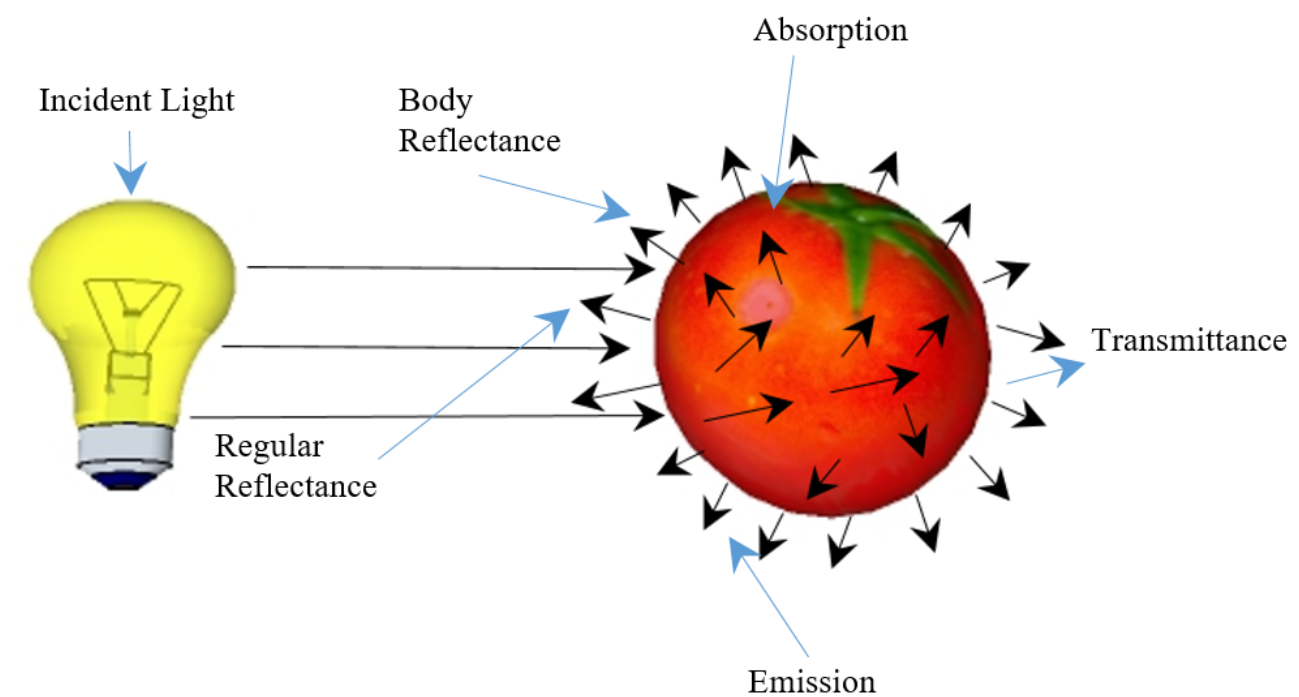

Figure 1. Schematic of the interaction between light and a fruit [5].

The optical properties of the lycopene molecule allow the absorption of ultraviolet and green electromagnetic regions because it has a structure of 40 carbons and eight isopropene units. These characteristics identify the family of carotenoids. The main functions attributed to carotenoids are fruit pigmentation, capture of light, and plant photoprotection [8-12]. The study of lycopene in fruits is very important because it has helpful antioxidant properties, which helps to avoid the generation of unstable molecules and free radicals that damage proteins, DNA, carbohydrates, and fats [13-15]. Some fruits that contain lycopene are tomato, watermelon, guava, grapefruit, papaya, and apricot. In Table 1, it can be observed that the fruits with the highest lycopene content are guava, tomato, watermelon, and papaya [16].

Table 1. Lycopene content of some fruits and vegetables [16].

\begin{tabular}{ccccccc}
\hline Fruit & Tomato & Watermelon & Guava & Grapefruit & Papaya & Apricot \\
\hline $\begin{array}{c}\text { Lycopene } \\
\mu \mathrm{g} / 100 \mathrm{~g}\end{array}$ & $8.8-42$ & $23-72$ & 54 & 33.6 & $20-53$ & $<0.1$ \\
wet weight & & & & & & \\
\hline
\end{tabular}

By 2023, lycopene is expected to generate an economic impact of $\$ 133$ million according to Industry ARC [17]. The aim of this work is to present a review of optical systems focused on the study of lycopene. For the analysis, an advantages and disadvantages comparison of the following optical systems is presented: the colorimeter, multispectral and hyperspectral imaging systems, high-performance liquid chromatography, and different spectroscopy types (IR, UV-VIS, Raman).

\section{Lycopene Nutraceutical Properties and Its Effects on Human Health}

Currently, the health sector focuses its research on foods that provide a benefit to humans due to their nutritional composition. Foods high in lycopene play an important role in the prevention of diseases. These include cardiovascular diseases, cataracts, cancer, osteoporosis, male infertility, and peritonitis $[13,15,18]$. The suggested dose of daily lycopene intake is 30 to $35 \mathrm{mg}$ according to Rao et al. [19], similarly suggesting that daily consumption is 5 to $7 \mathrm{mg}$ to maintain lycopene levels in blood and to combat oxidative stress, as well as the risks of chronic diseases. In the case of cardiovascular diseases, an intake of between 35 and $75 \mathrm{mg}$ is recommended. 
Figure 2 shows the mechanism for the prevention of diseases from [20]. The first phase of this mechanism considers the intake of lycopene, which is absorbed from 10 to $30 \%$ of the total content in the diet and the lifetime of this, in the blood, is 2 to 3 days [21-23]. Lycopene allows a reduction of reactive oxygen species (ROS), as it works as a mechanism to prevent chronic diseases. This is achieved with the increase of lycopene levels in the human body. Among the benefits provided are the regulation of gap genes, improvement of intercellular communication, hormone modulation, metabolism regulation and its improvement for the immune response, participation in carcinogenic metabolism, and in the metabolic pathway through the induction of enzymes.

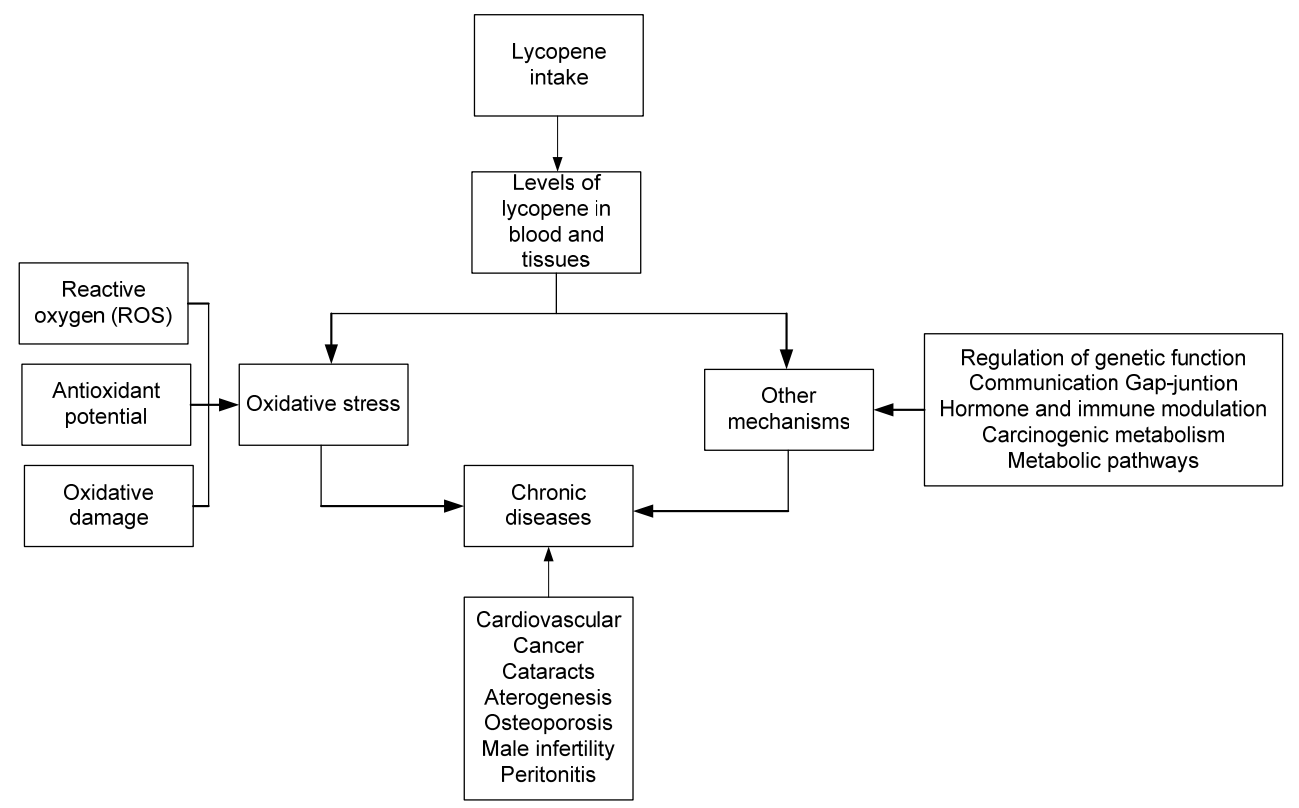

Figure 2. Role of lycopene in the prevention of chronic diseases [20].

\section{Effects in the Biological and Physical-Chemical Properties of Lycopene by Electromagnetic Wave Radiation}

The chemical structure of the lycopene molecule consists of 11 double bonds that allow the absorption of electromagnetic radiation between 200 and $490 \mathrm{~nm}$ [24]. Hashimoto et al. [25] reported that carotenoids absorb in the blue and green regions of the electromagnetic spectrum. The absorption in the blue region is due to the lycopene molecule, which has an outer electron that can move along the main carbon chain. It is conjugated and consists of alternating sequences of double $(C=C)$ and simple carbon bonds $(C-C)[26,27]$. Radiation in the visible blue region of the lycopene molecule is a factor that supports carotenoid biosynthesis. This can affect the antioxidant content and the product quality [28-30]. Figure 3 shows the chemical structures and absorption spectra of lycopene, $\alpha$-carotene, $\beta$-carotene, and lutein belonging to the same carotenoid's family. A characteristic highlighted of carotenoids is that their absorption spectra generally exhibit similar behaviors, and it has three peak values. In the case of lycopene, maximum absorption in acetone is found at 446 , 474 , and $504 \mathrm{~nm}[31,32]$.

When studying lycopene, it is necessary to consider the possible factors that can damage it. Amongst these are high temperatures, extreme $\mathrm{pH}$ values, and oxygen [33]. Radiation use allows inhibition and carotenoid stimulation. Also, the use of distant redlight radiation inhibited carotenoid generation in tomato and, with the red-light radiation, it was stimulated [30]. 
Lycopene

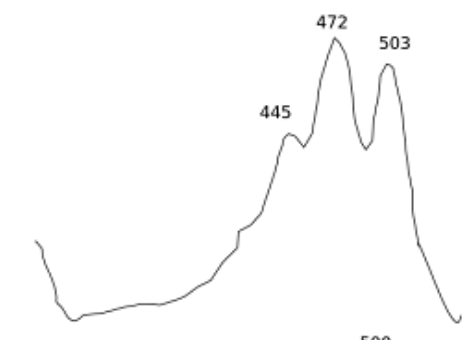

400

500

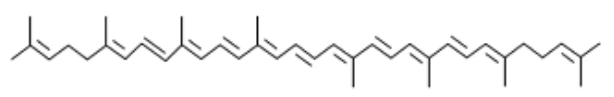

Beta-carotene

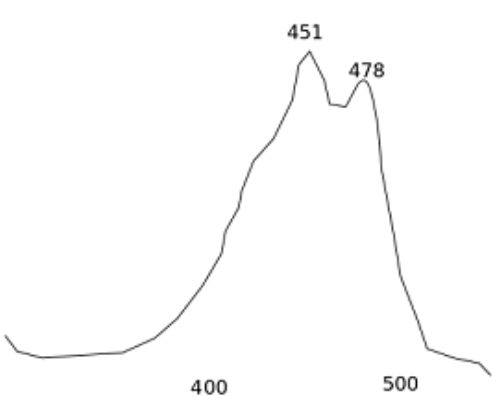

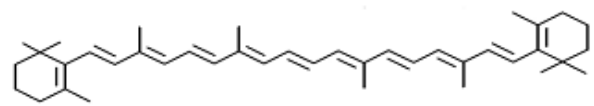

Alpha carotene
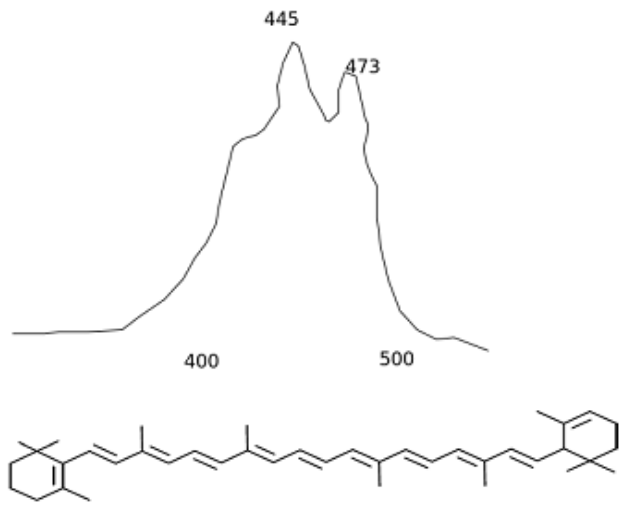

Lutein

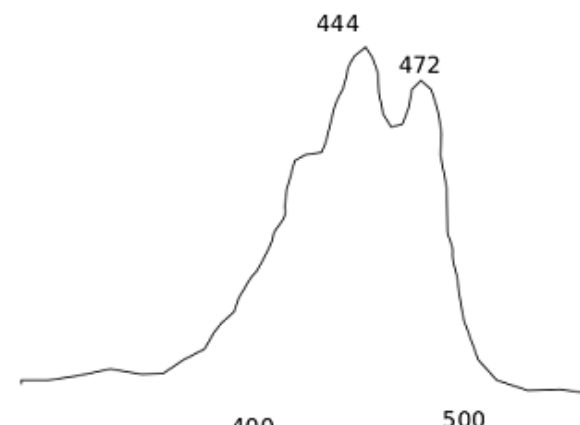

400

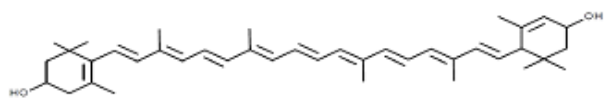

Figure 3. Chemical and molecular structures of selected carotenoids from Zielinska et al. [34].

Liu et al. [34] also established that the increase in carotenoid synthesis in tomatoes is logarithmic. In the study, 30 tomato samples in the breaking maturity stage with three variants of radiation for each analysis were used. The first treatment consisted of radiating the samples with red light $\left(243 \mathrm{mw} / \mathrm{cm}^{2}\right)$. The second one irradiated the samples with far red light $\left(488 \mathrm{mw} / \mathrm{cm}^{2}\right)$. The last treatment only isolated them in the dark. All samples were observed for $14 \mathrm{~h}$ per day, for a total of 8 days. Finally, they were kept in the dark. The results were: $692.5,345.6$, and $180.8 \mu \mathrm{g} / \mathrm{g}$ for the first, second, and third experiments, respectively.

\subsection{Biological and Chemical Effects by Radiation in Lycopene}

The food industry demands higher-quality food and durability and lower chemical waste content [35]. The quality of food can be affected by the following factors, such as the amount and intensity of the lighting that it is grown in, the temperatures to which the fruits are exposed, and the $\mathrm{CO}_{2}$ content in the environment [36]. These are related to the chemical reactions that generate lycopene. This process is called biosynthesis. The optimal temperature for biosynthesis is 22 to $26^{\circ} \mathrm{C}$ and the range under which it is affected is 30 to $35^{\circ} \mathrm{C}[32,37-40]$. Lycopene biosynthesis is shown in Figure 4, where the predecessor of this molecule can be seen. These include phytoene and $\varsigma$-carotene. Molecules derived from lycopene also appear, including $\delta$-carotene, $\alpha$-carotene, $\gamma$-carotene, and $\beta$-carotene. 


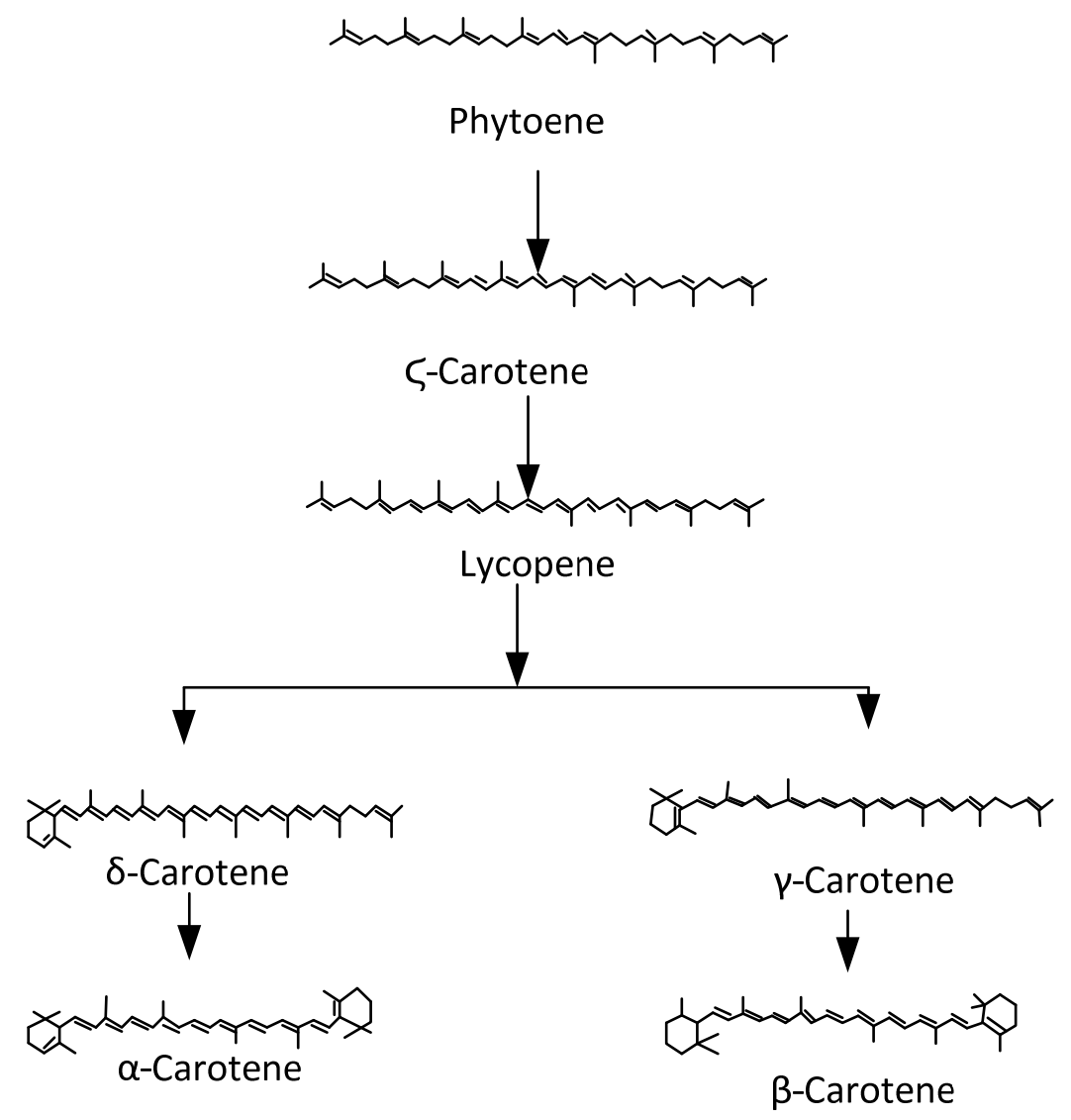

Figure 4. Simplified route of lycopene biosynthesis [39].

\subsection{Fluorescent Lighting}

Pesek et al. [41] explored the effects of radiation on vegetable juice with fluorescent light. For the investigation, they used two trials, and each trial had $2 \mathrm{~g}$ of juice. One sample was treated with fluorescent light at a constant intensity at $230 \mathrm{ft}-\mathrm{c}$ and $4{ }^{\circ} \mathrm{C}$ while the other sample remained isolated from illumination. The samples initially contained $3.0 \mu \mathrm{g} / \mathrm{g}$ of $\alpha$-carotene, $8.2 \mu \mathrm{g} / \mathrm{g}$ of $\beta$-carotene, and $62.9 \mu \mathrm{g} / \mathrm{g}$ of lycopene. They were exposed to radiation for four days and showed a reduction in antioxidants: $25 \%$ for lycopene, and $75 \%$ for $\alpha$-carotene and $\beta$-carotene. The authors concluded that the lycopene carbon rings at the ends of its chemical structure protect it from light degradation.

In another experiment, Lee et al. [42] reported lycopene's behavior at different temperatures $\left(50,100\right.$, and $150{ }^{\circ} \mathrm{C}$ ) and radiated with fluorescent light at $25^{\circ} \mathrm{C}$ for different periods. They observed that at $50{ }^{\circ} \mathrm{C}$, isomerization predominated in the first $9 \mathrm{~h}$ and then degradation started. In contrast, for conditions between 100 and $150{ }^{\circ} \mathrm{C}$, degradation proceeded faster than isomerization.

\subsection{UV-C Radiation}

The use of UV-C radiation generates positive biological effects, such as a reduction of food decomposition, and germicidal and antimicrobial effects [43,44]. Bhat [45] explored the impact of treating tomato juice by using ultraviolet radiation (UV-C) at different time intervals $(0,15,30$, and $60 \mathrm{~min})$. In the study, the physicochemical properties, antioxidant activity, microbial load, and the color were evaluated. The researcher determined, by using color analysis, the value of the $\mathrm{L}^{*}$ coordinate, which increased significantly, and for the coordinates $\mathrm{a}^{*}$ and $\mathrm{b}^{*}$, the values decreased after the treatments with UV-C. Regarding the content of lycopene, no significant changes were perceived.

Liu et al. [34] used UV-C treatments and red and solar light on the tomato. They analyzed the behavior of the carotenoids, skin color, firmness of the tissue, and soluble 
reactive solids during the experiment. They found that sunlight and red light increased the lycopene content in tomato but UV light degraded it. They also mentioned that soluble solids are not affected by this type of radiation. Another similar study on tomato was proposed by Noga et al. [46]. They used handlings with red light and with short exposure to UV radiation, and achieved an increase of lycopene, $B$-carotene, total flavonoids, and phenolic compounds. Table 2 shows the four treatments used and the concentration of lycopene obtained in periods of 5, 10, 15, and 20 days. The control treatment was kept in the dark. For the treatments dark + UV and red light $+\mathrm{UV}$, the samples were irradiated with $4.98 \mathrm{~kJ} / \mathrm{m}^{2}$ of UV light for $30 \mathrm{~min}$. In the treatments red light and red light $+\mathrm{UV}$, tomatoes were irradiated with a special LED lighting module. The spectrum of the light was composed of $60 \%$ UV-B (280-320 nm with a dominant peak at $290 \mathrm{~nm}), 30 \%$ UVA $(320-400 \mathrm{~nm}), 4 \% \mathrm{UV}-\mathrm{C}(200-280 \mathrm{~nm})$, and $6 \%$ visible light $(400-700 \mathrm{~nm})$. The red illumination was applied throughout the storage time, with a peak at $665 \mathrm{~nm}$, equivalent to an available radiation photosynthesis (PAR) of $113 \mu \mathrm{mol} / \mathrm{m}^{2}$ per day. The procedure that presented a significant change was the red and UV light, and this occurred between days 5 and 10 .

Table 2. Lycopene content, per kg tomato irradiated by red light + UV [34].

\begin{tabular}{ccccccc}
\hline Treatment & $\begin{array}{c}\text { Exhibition } \\
\text { Time }\end{array}$ & \multicolumn{5}{c}{ Lycopene Concentration mg/Kg } \\
& \multicolumn{10}{c}{ 0 Days } & 5 Days & 10 Days & 15 Days & 20 Days \\
\hline Dark (Control) & 24 h & 42.07 & 44.22 & 131.92 & 961.37 & 871.16 \\
\hline Dark + UV & $\begin{array}{c}\text { Only two UV } \\
\text { radiation of } \\
15 \text { min daily }\end{array}$ & - & 54.61 & 49.60 & 855.14 & 850.84 \\
\hline Red light & 24 h & - & 40.92 & 1049.08 & 1176.50 & 1507.17 \\
\hline Red light + UV & $\begin{array}{c}24 \text { h of red light } \\
\text { with two UV } \\
\text { radiation of } \\
15 \text { min daily }\end{array}$ & - & 54.65 & 1280.18 & 1324.43 & 1413.91 \\
\hline & & & & & \\
\hline
\end{tabular}

\section{4. $\gamma$-Radiation}

Kumar et al. [47] experimented with $\gamma$-rays and magnetic fields to establish a relationship with the behavior of the biochemical attributes that influences the maturation and quality of the fruits. Radiation with $\gamma$-rays showed reductions in maturation, in the synthesis of lycopene, and in the production of ethylene and reactive oxygen species (ROS). Silva-Sena et al. [48] studied the effect of $\gamma$-irradiation on the carotenoids and vitamin C contained in papaya. The lycopene of this fruit was not affected by the irradiation but the other carotenoids were. With this, the increase of carotenoids in the ripening of the papaya was delayed.

\section{Current Systems for Estimating Lycopene}

It is necessary to highlight that these optical systems have elements, such as multiple lenses, mirrors, prisms, and windows. In this sense, the measurement of lycopene is determined with the interaction of light and the optical properties of the samples [49]. This section deals with the optical systems for the identification, estimation, and measurement of lycopene. These can be grouped in high-performance liquid chromatography (HPLC), colorimetry, UV-Vis spectroscopy, IR spectroscopy, Raman spectroscopy, and multispectral and hyperspectral imaging systems. The analysis of these was focused on the mode of acquisition of lycopene information, the region of the electromagnetic spectrum, and the processing of the study sample. 


\subsection{High-Performance Liquid Chromatography (HPLC)}

In the food sector, one of the main techniques that allows identification of the internal composition of food is high-performance liquid chromatography (HPLC). This lycopene measurement technique requires its extraction from the food. This is a process used to obtain an oil that contains the carotenoid. Conventionally, it is done with the use of solvents, heat, and agitation to separate the compounds from the sample. The HPLC technique employs a non-polar stationary phase and a mobile phase that acts as a carrier for the sample can be composed of various solvents. The components of the solution migrate according to the non-covalent interactions of the compounds with the column. These chemical interactions determine the separation of the contents in the sample [50]. Figure 5 shows the basic elements that integrate HPLC. These are the solvents of the mobile phase, the pumping system, the chromatograph, the injection system, the column for liquids, the detectors, waste, the control, and processing. The limit of detection (LOD) and limit of quantitation (LOQ) are important characteristics used to evaluate the efficiency of HPLC. Cámara et al. [51] reported that this method can determine concentrations of lycopene $\mathrm{LOD}=0.6 \mu \mathrm{g}$. For the case of $\mathrm{LOQ}=0.11$, this parameter is related to the lowest concentrations with acceptable repeatability and accuracy.

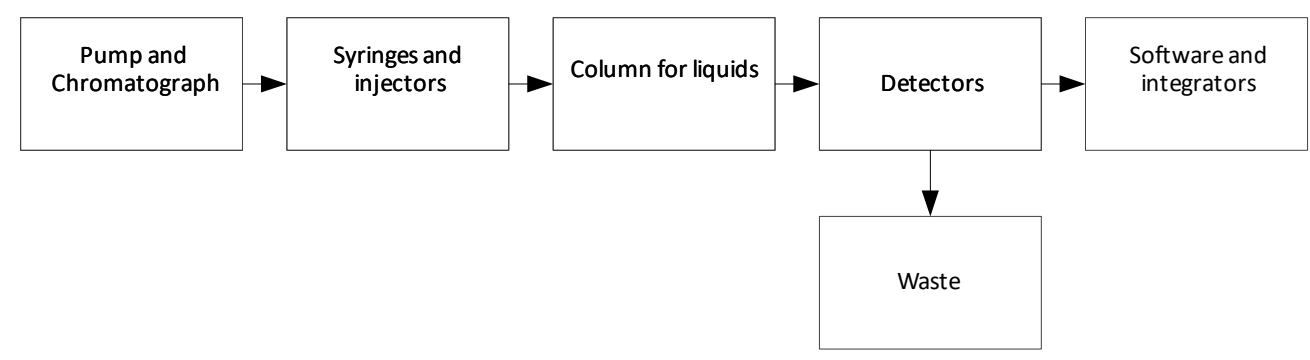

Figure 5. Elements that integrate a high-performance liquid chromatograph.

Figure 6 shows the optical system used by HPLC to identify different study molecules. It has seven elements, which are a UV-lamp (1), lamp mirror (2), flow cell (3), fold mirror (4), programmable or fixed slit (5), grating (6), and diode array detector (DAD) (7). Its operation uses the UV-lamp light, which is focused by the lamp mirror, towards the inlet of the flow cell. Subsequently, the light is guided by the optofluidic waveguides to the opposite end of the flow cell. This is focused on the fold mirror using the holographic grating. Subsequently, the light is scattered over the diode array detector (DAD) in order to have simultaneous access to all the information related to the wavelengths [37].

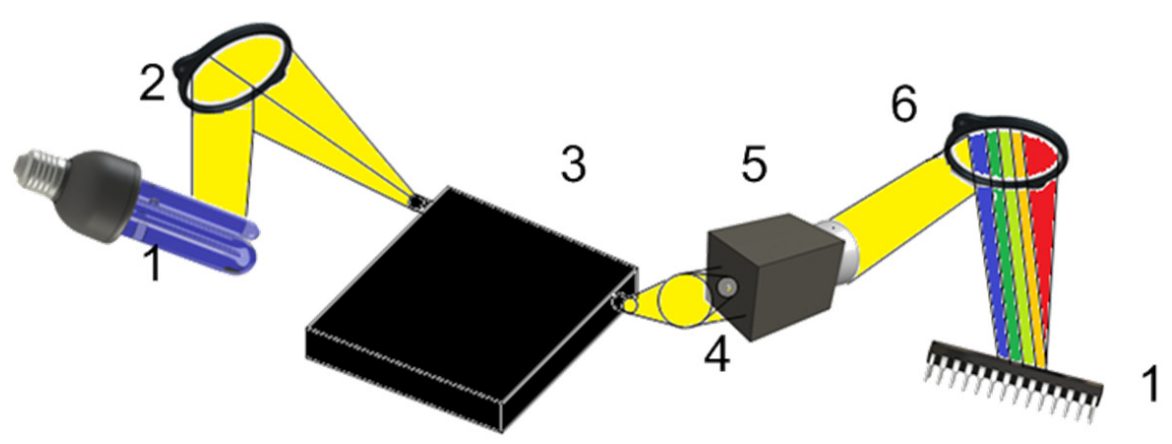

Figure 6. Elements that integrate the optical system of HPLC [37].

\subsubsection{Lycopene Extraction Methods}

The extraction of lycopene from food is relevant to facilitate the displacement of the same in the mobile phase, and this allows the optical detectors of the HPLC to identify and subsequently quantify the sample to be studied. Perkins-Veazie et al. [52] proposed a method that allows lycopene to be obtained from different varieties of watermelon. They 
used $2 \mathrm{~g}$ of watermelon tissue puree, $50 \mathrm{~mL}$ of hexane, $25 \mathrm{~mL}$ of acetone, $25 \mathrm{~mL}$ of ethanol, and $0.05 \%(w / v)$, butylated hydroxytoluene (BTH). The mixture was placed in a wristaction shaker for $10 \mathrm{~min}$ at $5{ }^{\circ} \mathrm{C}$ and then stirred for another $5 \mathrm{~min}$, adding double-distilled water. The sample settled for $15 \mathrm{~min}$ to achieve separation of the polar and non-polar layers. Subsequently, duplicates of $1 \mathrm{~mL}$ each of the hexane layer were removed for measurement. In the case of Skoog et al. [50], to extract lycopene from tomato, the samples of the fruit were homogenized by means of a blender for $3 \mathrm{~min}$ and the water content was measured by the constant weight method in a vacuum oven at $70{ }^{\circ} \mathrm{C}$. The carotenoids were separated from the homogenate formed by a hexane, acetone, and ethanol mixture (50:25:25). It was stirred for 15 min during phase separation and the sample was settled. After this, the sample was settled. Subsequently, the polar and non-polar layers were filtered and separated [53]. Likewise, Cámara et al. [51] described a method of extracting beta-carotene and lycopene from fresh tomato, tomato sauce, ketchup, tomato juice, tomato puree, carrots, watermelon, peach, green chili, and medlar. The analytical method of extraction of the samples used the mixture of THF/ACN/methanol solvents (15:30:55 v/v/v). This extraction process required shaking the samples for $30 \mathrm{~min}$. Subsequently, the lycopene was separated from the food matrix by layers.

\subsubsection{Chromatographic Conditions}

Cámara et al. and Barba et al. [51,54] handled the same characteristics in their chromatographer in order to quantify lycopene: a $\mu$ Bondapack C18 column (300 mm $\times 2 \mathrm{~mm})$, $10 \mu \mathrm{m}$ pore size, a $\mu$ Bondapack $\mathrm{C} 18$ precolumn $(20 \mathrm{~mm} \times 3.9 \mathrm{~mm}), 10 \mu \mathrm{m}$ pore size, mobile phase 90:10 methanol/ACN $(v / v)+9 \mu \mathrm{M}$ TEA, flow rate $0.9 \mathrm{~mL} / \mathrm{min}$, temperature of the column of $30^{\circ} \mathrm{C}$, and a detection wavelength $\lambda=475 \mathrm{~nm}$. In the case of Arias et al. [1], they used a $4.6 \times 250 \mathrm{~mm}, 5 \mu \mathrm{m}$ polymer C18 column for the isolation of carotenoids, with a mobile phase isocratic system that was composed of methyl alcohol and methyl tert-butyl ether in a ratio of 3:7. The wavelength range used was 420-530 nm, and the length for the identification of the lycopene reported was $471 \mathrm{~nm}$. On the other hand, Perkin et al. [53] used a Microsorb $277 \mathrm{MV}-\mathrm{C}-18$ column with a $470 \mathrm{~nm}$ detection wavelength and solvent proportion of acetonitrile (40\%), methanol (20\%), methylene chloride $(20 \%)$, and hexane (20\%). Pedro et al. [55] determined lycopene and $\beta$-carotene $\left(\mathrm{mg} \mathrm{kg}^{-1}\right)$ using a Shimatzu HPLC (Shimatzu, Co., Kyoto, Japan) equipped with a CTO-10A column furnace, a Sil-10A automatic injector, LC-10AD pumps, and a UV-visible SPD-10AV detector at $473 \mathrm{~nm}$. The separation was achieved using a RP18 Zorbax ODS column $(5 \mu \mathrm{m}, 15 \times 0.46 \mathrm{~cm})$. The mobile phase was MetOH/THF/ $\mathrm{H}_{2} \mathrm{O}$ (67:27:6), Socratic at $1.0 \mathrm{~mL} / \mathrm{min}$.

\subsection{Colorimeter}

Color is one of the main indicators used to identify the maturity and physical and chemical composition of fruits and vegetables [56-59]. The colorimeter is an instrument that uses the CIELAB color space and provides unified measurements. It has a perception closer to that of humans [60-62]. The CIELAB color space consists of a coordinate space of three orthogonal components, which are $L^{*}$ (clarity), $a^{*}$ (redness), and b* (yellowness) [59,62,63].

Various investigations have used color for the measurement of lycopene. Arias et al. [56] analyzed the use of several relationships for the measurement of lycopene in tomato using the coordinates $\mathrm{L}^{*}, \mathrm{a}^{*}, \mathrm{~b}^{*}, \mathrm{c}^{*}$, and $\mathrm{h}^{*}$, where the selection of these was in the stages of green maturation, yellowish with some pink regions, orange, soft red, red, intense red in firm fruit, and intense red with soft fruit. Color measurement of tomatoes in the equatorial region of the surface using a Minolta Chroma Meter CR-200 (Minolta) colorimeter (Camera Co. Ltd., Osaka, Japan) determined that the coordinate $\mathrm{a}^{*}$ shows a linear correlation with the stages of maturation of the tomato. Splicing was observed in the groups of firm red and intense red, the luminosity factor $L^{*}$ decreased during the first five stages of maturation and then remained constant, and the $b^{*}$ value increased through the first four stages of maturity due to the synthesis of $\beta$-carotene and presented a low correlation with the maturity states. 
Different models focus on the measurement of lycopene using the color space Cielab. Vazquez-Cruz et al. [1] proposed a model based on an artificial neural network (RNA). Its architecture has six entries, two hidden layers of 13 and eight neurons, respectively, and an output for the prediction of lycopene. The entries used were $L^{*}, a^{*}, b^{*}, a^{*} / b^{*}$, and the leaf area index (LAI). The learning ratio was 0.4 , with a time of 0.6 and the coefficient of the relationship was 0.98 . Tilahun et al. [64] performed a prediction model of lycopene and $\beta$-carotene in tomatoes, using the color correlation coefficients, which were, $\mathrm{a}^{*}, \mathrm{a}^{*} / \mathrm{b}^{*}$, and $\left(a^{*} / b^{*}\right)^{2}$. Another investigation was that of Ye et al. [65], who used tomato of the Momotaro breed to create a model for lycopene estimation. They used a gram of tomato tissue, and the quantification was performed spectrophotometrically with a biophotometer (B PM-10 Bio, Taitec Corporation, Saitama, Japan). They used a standard solution of lycopene with concentrations of $0,2,5,10$, and 15 ppm and a colorimeter (NF333, Nippon Denshoku Industries Co., Ltd., Tokyo, Japan). The system was performed on an Android 4.2.2 tablet. Its operation consisted of capturing an image or images with the standard colors to calculate the values and reference chromaticity. Subsequently, they determined the color differences between the test fruit and each of the standard colors. The model for estimating lycopene used the color relationship $\left(a^{*} / b^{*}\right) 2$. Table 3 shows the factor with the highest correlation with the lycopene content, which is $\mathrm{a}^{*} / \mathrm{b}^{*}$, which was used by $[1,54,64]$. For the case of Ye et al. [65], they used the same squared correlation factor. Moreover, Hue and Chroma did not present an $\mathrm{R}^{2}$ correlation lower than 0.7 with the lycopene content as reported by Arias et al. and Ye et al. [56,65].

Table 3. Comparison of lycopene measurement systems using color.

\begin{tabular}{|c|c|c|c|c|}
\hline \multirow{2}{*}{ Factor } & $\begin{array}{l}\text { Arias et al. } \\
\quad(2000)\end{array}$ & $\begin{array}{l}\text { Vazquez-Cruz } \\
\text { et al. (2013) }\end{array}$ & $\begin{array}{l}\text { Tilahun et al. } \\
\text { (2018) }\end{array}$ & $\begin{array}{c}\text { Xujun Ye and Zhang } \\
\text { (2018) }\end{array}$ \\
\hline & $\begin{array}{c}\text { Linear Regression } \\
\mathbf{R}^{2}\end{array}$ & $\begin{array}{c}\text { Linear Regression } \\
\mathbf{R}^{2}\end{array}$ & Linear Regression $\mathbf{R}^{2}$ & Linear Regression $\mathbf{R}^{2}$ \\
\hline $\mathrm{L}^{*}$ & 0.90 & 0.908 & 0.49 & 0.83 \\
\hline$a^{*}$ & 0.87 & 0.909 & 0.92 & 0.78 \\
\hline$a^{2 *}$ & $x$ & $x$ & $x$ & 0.72 \\
\hline$b^{*}$ & 0.09 & 0.02 & 0.52 & 0.50 \\
\hline$b^{2 *}$ & $x$ & $x$ & $x$ & 0.48 \\
\hline$\left(a^{*} / b^{*}\right)$ & 0.90 & 0.980 & 0.94 & 0.76 \\
\hline$\left(a^{*} / b^{*}\right)^{2}$ & 0.86 & $x$ & 0.42 & 0.81 \\
\hline $\begin{array}{c}\text { Hue } \\
\text { Tan }-{ }^{1}\left(\mathrm{~b}^{*} / \mathrm{a}^{*}\right) \\
\end{array}$ & 0.44 & $x$ & $x$ & $x$ \\
\hline $\begin{array}{c}\text { Chroma } \\
C^{*}=\left(\left(a^{*}\right)^{2}+\left(b^{*}\right)^{2}\right)^{1 / 2}\end{array}$ & 0.67 & $x$ & $x$ & 0.36 \\
\hline $\begin{array}{l}\text { Lycopene } \mathrm{mg} / 100 \mathrm{~g} \\
\text { wet weight }\end{array}$ & 0.91 & 0.586 & $x$ & $x$ \\
\hline
\end{tabular}

$\mathrm{X}=$ Descriptor not reported by the author.

\subsection{Ultraviolet-Visible (UV-Vis) and Infrared (NIR) Spectroscopy}

Spectroscopy is used to identify maturity states and the internal composition of some fruits and vegetables. It uses optical properties, such as the reflectance and absorbance, in a range of 780-2526 nm [66]. An important aspect in spectroscopy is that absorption causes fundamental vibrations. They are related to the functional groups $-\mathrm{CH},-\mathrm{NH},-\mathrm{OH}$, and -SH $[67,68]$. The (NIR) spectroscopy consists of irradiating the study element with a light that can be reflected, absorbed, or transmitted. Once the measurement of the sample is made, the composition is established, as well as the structure, depending on the amount of light measured and the wavelength [69-71]. Figure 7 shows the elements integrating the 
optical system of the type of (NIR) spectroscopy: light source of the halogen or tungsten type, a monochromator, a sample holder, and detectors.

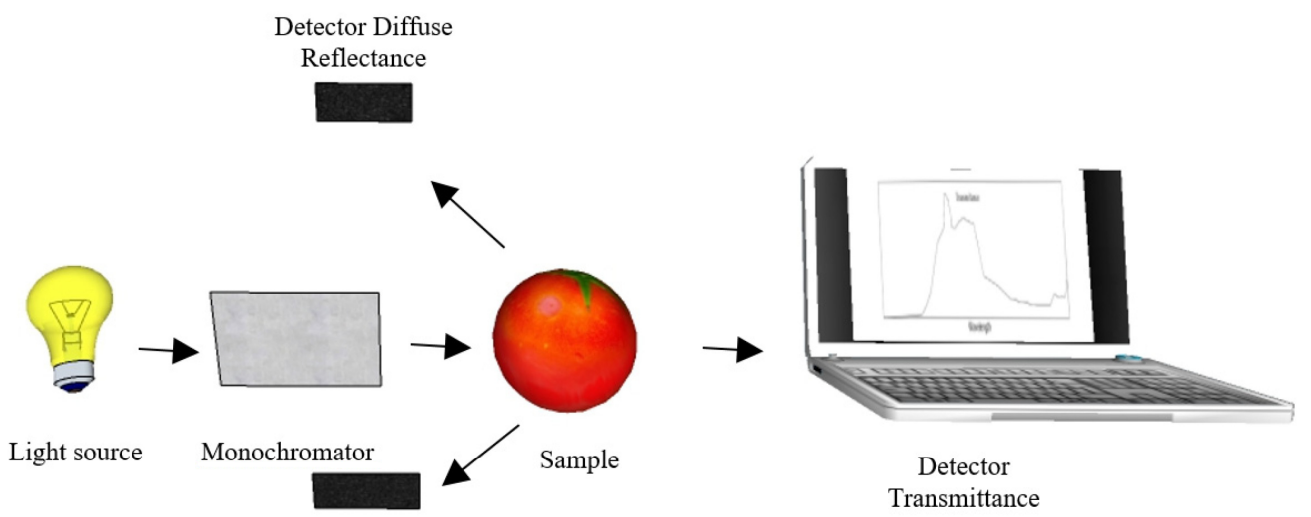

Figure 7. Elements that integrate an optical system of spectroscopy (NIR) [72].

Li et al. [57] identified the maturity stages of the tomato using spectroscopy (Vis-Nir). Through this, the reflectance spectra were obtained in the range 380 to $2500 \mathrm{~nm}$; these present changes in the region of 400-700 nm and allow the fruits to be classified as shown in Figure 8. Similar studies allow the measurement of lycopene, as in the case of Tamburini et al. [73], who developed an online spectroscopy (NIR) system. For this, they selected the range of 900 to $1700 \mathrm{~nm}$ with the intention of measuring lycopene, $\beta$-carotene, and total soluble solids in watermelon (Citrullus lanatus). This system used the NIR On-Line RX-One (Buchi, Flawil, Switzerland), which is made up of a diode array detector (DAD) and a dual tungsten-halogen lamp. In 2013, they performed tests with watermelons on a conveyor belt without movement. From these, two spectra were obtained from two selected regions. By 2014, the four-sided spectra with the moving band were obtained. Three speeds were used for the band, which were 2100, 2400, and $2700 \mathrm{rpm}$, to obtain a total of 720 spectra. Finally, in 2015, they obtained 35 spectra randomly, using new fruits. The spectra obtained during the study were treated by the standard normal variance (SNV) and the first derivative for the reduction of noise and unwanted information. With the use of principal component analysis (PCA), they identified three groups of data that offer significant information. These groups are the year of sampling, the climate that is associated with the frequency of rains, extreme temperatures, and the physical-chemical characteristics. One aspect to highlight is that these factors together with the radiation modify the lycopene content in the fruits. The reported correlations for lycopene in the case of $\mathrm{R}^{2}$ cal calibration were 0.877 ; for the validation $\mathrm{R}^{2}{ }_{\mathrm{cv}}, 0.756$; and finally, for the external validation, $R^{2}$ Ext, the result obtained was 0.805 .

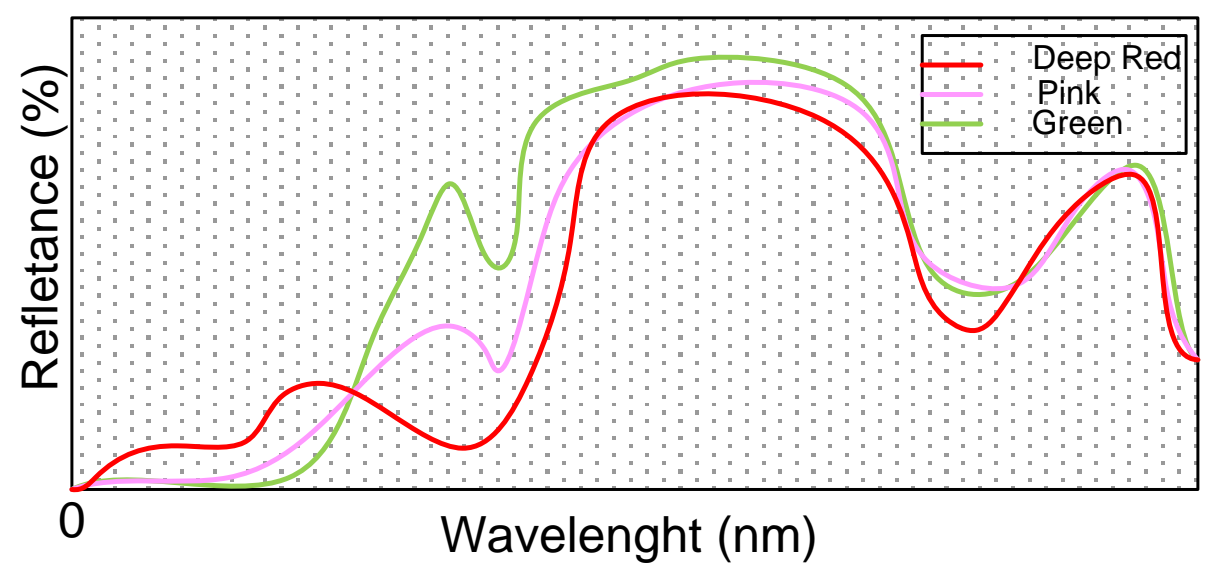

Figure 8. Identification of the maturity of tomato using spectroscopy (NIR) from Li et al. [57]. 
Tilahun et al. [66] performed a prediction model for lycopene and $\beta$-carotene in tomatoes, using a laptop and Vis-NIR spectra. In the development of the model, they used a range of 500-1100 $\mathrm{nm}$ and reported some relationship coefficients for the lycopene calibration of $R^{2}{ }_{C}=0.89092$ and in the case of $\beta$-carotene $R^{2}{ }_{C}=0.88158$. The correlation coefficients for the predictions were $R^{2}{ }_{P}=0.85106$ and $R^{2}{ }_{P}=0.77353$. The transmittance spectra of the intact tomatoes were obtained with a Vis-NIR spectrometer (Life \& Tech, CO, Ltd., Yongin, Korea) using a halogen lamp as the Vis-NIR light source. The measurement on the fruit was done six times to reduce the noise, obtaining a total of 3500 data for each measurement with a spectrum resolution of $0.2 \mathrm{~nm}$. Together with this, a total of 1160 spectra were obtained, which represent the breaking, pink, and red maturity state of the fruits in the study. For the calibration and cross-validation process, they used 50\% of the spectra for each stage. The spectra obtained from the fruits were processed to eliminate unwanted information and noise. Original spectra were treated by a Hanning Window, standard normal variance (SNV), multiplicative dispersion correction (MSC), and the first derivative. Another study focused on lycopene measurement is that of Pedro et al. [55], who analyzed, in a non-destructive way, the soluble solids and carotenoids in tomato products. The tomato spectroscopy NIR was acquired after opening the samples. The aliquot of the fruit was placed at the bottom of a Petri dish (Schott 2375548 05), and the readings were performed on a Büchi NIRLab Spectrometer N-200 (Büchi Labortechnik AG, Postfach) equipped with a diffuse reflectance cell MSC-100. The method for the calibration models was that of partial least squares (PLS). For this, 42 samples were used during the calibration stage, with 126 spectra obtained. In the validation, 37 samples and 111 spectra were used. The proposed models used three regions that were 1000 to $1250 \mathrm{~nm}, 1250$ to $1666.67 \mathrm{~nm}$, and 1666.67 to $2500 \mathrm{~nm}$. The original spectra were pre-processed by applying a medium smoother with a window width of 15 wave numbers. Among the proposed models, the main difference is the number of spectrum regions and the number of factors or main components they use. The best model reported by Pedro et al. [55] is the one that used the treatment with multiplicative signal correction (MSC) and the use of the spectrum from 1250 to $2500 \mathrm{~nm}$ using 5 factors. The correlation factor was 0.9996 and a mean squares error of prediction of 21.5779 .

\subsubsection{Raman Spectroscopy}

Raman spectroscopy has been used to measure the lycopene content. The technique involves the use of high-energy monochromatic light, such as a laser, which disperses over the molecules and interacts with the photons of the sample. The study matrix does not require a complex preparation and they can be studied in either glass or polymer packaging [74-77]. Typical Raman measurements employ the highest intensity that is related to the longest wavelength and Stokes scattering [77]. The measurement is carried out using the vibrations of the stretches of the C-C bonds (v1) of the polyene chain. The other stretch of interest is the bond $\mathrm{C}=\mathrm{C}$ and the deformation $\mathrm{C}-\mathrm{CH} 3$, respectively known as (v2) and (v3) [78-83].

Withnall et al. [83] reported two peaks of greater magnitude for the estimation of carotenoids in tomato. The location of these is in the spectral regions of 1100-1200 and $1400-1600 \mathrm{~cm}^{-1}$. In Figure 9, the study of the behavior of the maturity of the tomato is presented. It can be seen that the peaks coincide with those reported by Withnall et al. [83]. Measurement of the lycopene content was achieved using a portable Raman spectroscopy system and the maximum concentration of lycopene occurred in the state of deep red maturity [84]. 


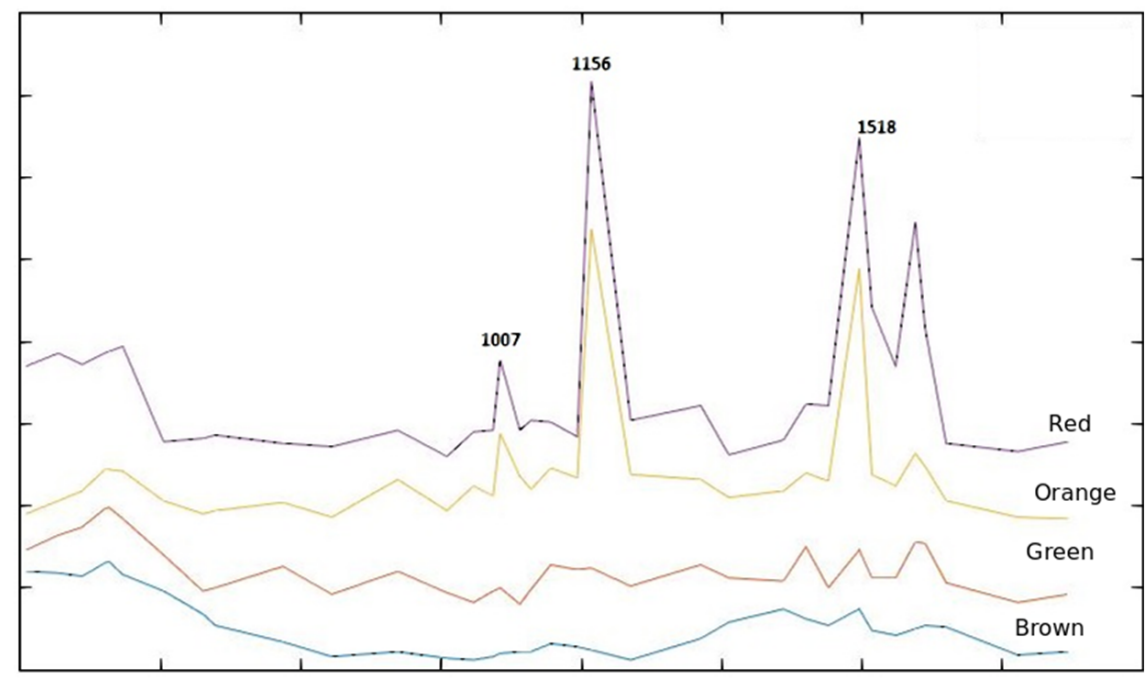

Figure 9. Spectra of tomato maturity behavior using Raman spectroscopy [84].

Qin et al. [85] developed a spatial compensated Raman spectroscopy system (SORS), for a non-destructive evaluation of the internal maturity of the tomatoes. The system shown in Figure 10 consists of a $785 \mathrm{~nm}$ laser in the spectra range 4000 to 50,000 nm, a 16-bit camera with $1024 \times 256$ pixels, and a Raman imaging spectrometer. This system accepts light by means of an input slot $5 \mathrm{~mm}$ long by $100 \mathrm{~mm}$ wide. The spectrometer works in the range of 779-1144 $\mathrm{nm}$. The focusing unit consists of a band pass filter, a focus lens, and an optic fiber collimator. The biological materials' auto-flowering difficulty was solved by the curve adjustment method called modified polynomial means [86]. The method used to identify the lycopene was through the divergence of spectral information (SID) and relative entropy.

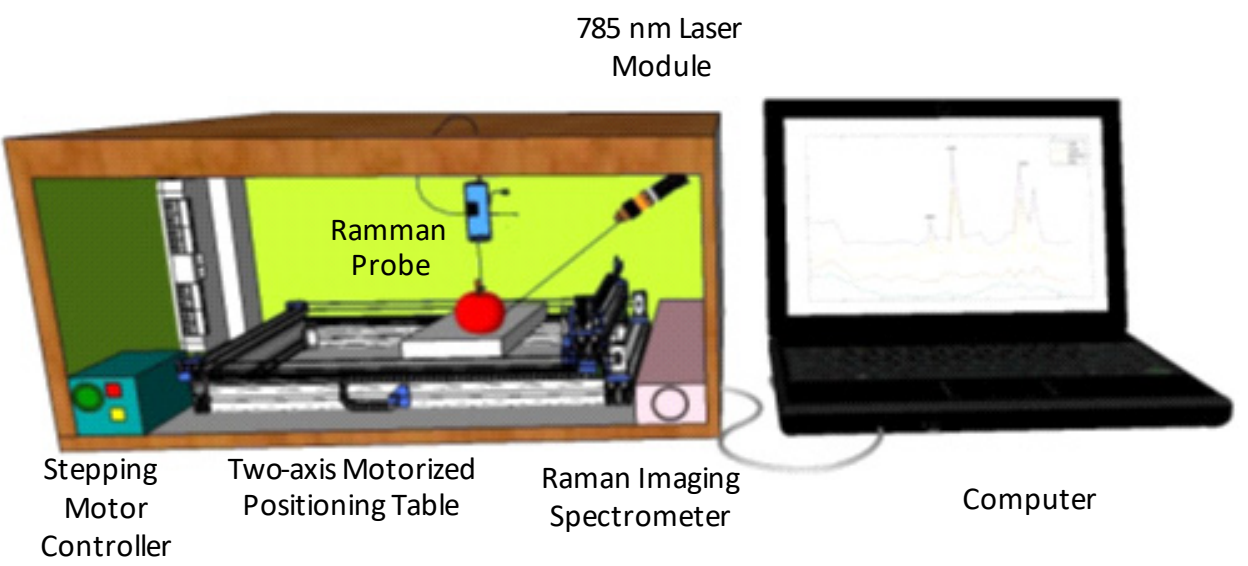

Figure 10. Raman spectroscopy system for lycopene measurement [86].

\subsubsection{Multispectral (MSI) and Hyperspectral (HSI) Imaging Systems}

The optical systems of multispectral and hyperspectral images are used to acquire both the spatial and spectral information of a product by combining traditional methods of imaging and spectroscopy. With them, internal and external information is obtained from the study matrix [86]. Qin et al. [87] performed the measurement of the optical properties of fruits and vegetables. The multispectral system shown in Figure 11 is made up of a light source and a hyperspectral image unit. The unit contains a focusing lens and a spectrograph. The broadband light was coupled to an optical fiber and a micro lens to generate a $1.0 \mathrm{~mm}$ diameter beam, which impinges on the sample at $15^{\circ}$ from the vertical direction. The images were captured in online scan mode covering a spectral range between 200 and $1100 \mathrm{~nm}$. The difference between the traditional UV-VIS and NIR spectroscopy techniques is based on the regional study of the 
matrix. In the case of multispectral and hyperspectral images, they evaluate the entire surface of the element of study, and provide spatial and spectral information [85].

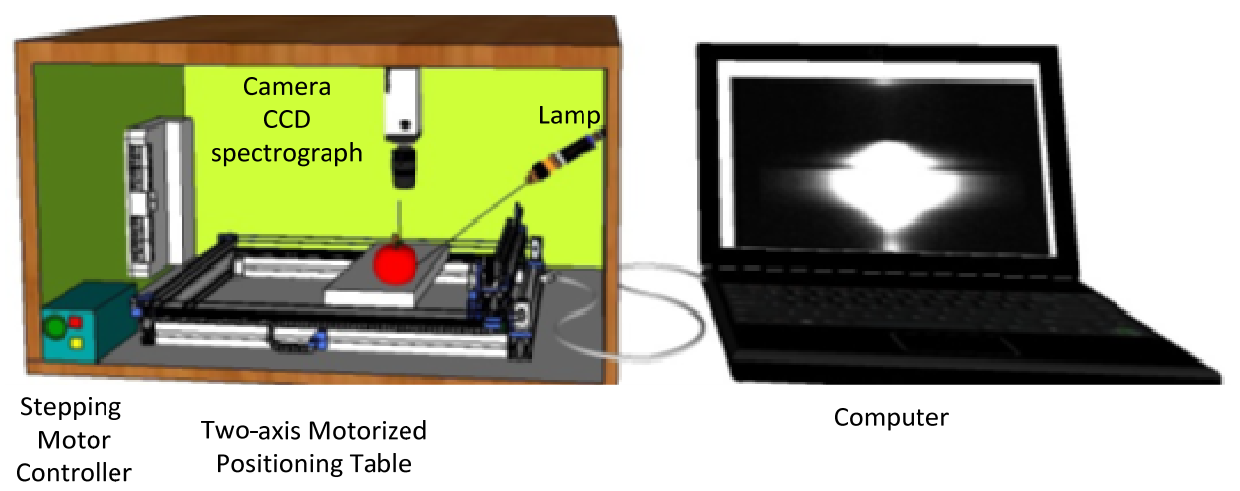

Figure 11. Multispectral system for lycopene measurement from Qin et al. [85].

Liu et al. [9] developed a system using multispectral images with chemo-metric methods to measure lycopene and the phenolic compounds in tomato. This system operated with 19 wavelengths from 405 to $970 \mathrm{~nm}$. The total samples used for calibration and validation were 162 fruits in different stages of maturity. When calibrating, they used two-thirds of the total of fruits and the rest during validation. The proposed models to measure lycopene are partial least squares regression (PLS), the least squares support vector machine (LS-SVM), and the backpropagation neural network (BPNN). According to its results, BPNN obtained the best results for its $\mathrm{R}^{2} \mathrm{C}$ calibration of 0.957 and the $\mathrm{R}^{2} \mathrm{p}$ prediction of 0.938 .

The research by Polder et al. [7] measured the superficial distribution of carotenes and chlorophyll in mature tomatoes using imaging spectrometry and PLS. The recorded range was 400 to $700 \mathrm{~nm}$ with a resolution of $1 \mathrm{~nm}$. The images were recorded using two illuminators Dolan-Jenner PL900 (Andover St. Lawrence, Massachusetts, USA), with quartz halogen lamps of $150 \mathrm{~W}$ in the range of 380 and $2000 \mathrm{~nm}$. The root mean square error of the lycopene concentration in one pixel was 0.95 and for the base tomato it was 0.96. Here, $500 \mathrm{mg}$ samples of the fruit were milled with liquid nitrogen and $4 \mathrm{~mL}$ of acetone with $50 \mathrm{mg}$ of $\mathrm{CaCO}_{3}$. To the granules obtained after centrifugation, lycopene was extracted with $4 \mathrm{~mL}$ of acetone, $2 \mathrm{~mL}$ of hexane, and $5 \mathrm{~mL}$ of acetone: hexane (4:1). All solvents contained $0.1 \%(w / v)$ butylated hydroxytoluene (BHT).

Table 4 summarizes the application of different optical systems for the estimation of the lycopene content. The correlation coefficients are reported with the lycopene, instrumentation, wavelengths for the estimation of the same, treatment of the matrix, type of vegetable and fruit, acquisition method, and range of measurement. In the same table, the use of spectroscopy is highlighted, which allows a good correlation with tomato lycopene of $R=0.996$ to be obtained. The proposed system uses the spectrum regions 4000 to $6000 \mathrm{~cm}^{-1}$ and 6000 to $8000 \mathrm{~cm}^{-1}$, together with an MSC treatment. Another optical system that has a good correlation with the lycopene content in tomato is vegetable color measurement using the correlation $\mathrm{a}^{*} / \mathrm{b}^{*}$. It should be noted that high-performance liquid chromatography is commonly used for the validation of lycopene measurement systems. The relevance is that it allows quantification of the correlation between the states of maturity of the fruits when using the absorbance. The advantage of using this optical system is that it allows the creation of prediction models of lycopene content in tomato sauce, ketchup, tomato juice, tomato puree, carrots, watermelon, peach, green pepper, and medlar. HPLC measurements have the disadvantage that it requires a process of extraction of lycopene in the fruits. In this sense, the process is destructive and involves the use of toxic solvents. Furthermore, an important factor is the choice of a suitable mobile phase to achieve an adequate separation of this carotenoid. The use of spectral images and NIR spectroscopy presents a wide range of estimation of the lycopene content with $2.65-151.75(\mathrm{mg} / \mathrm{kg})$ [73] and in the case of spectral images it is 7.52-139 mg/g [7]. 
Table 4. Comparison of lycopene detection and measurement methods.

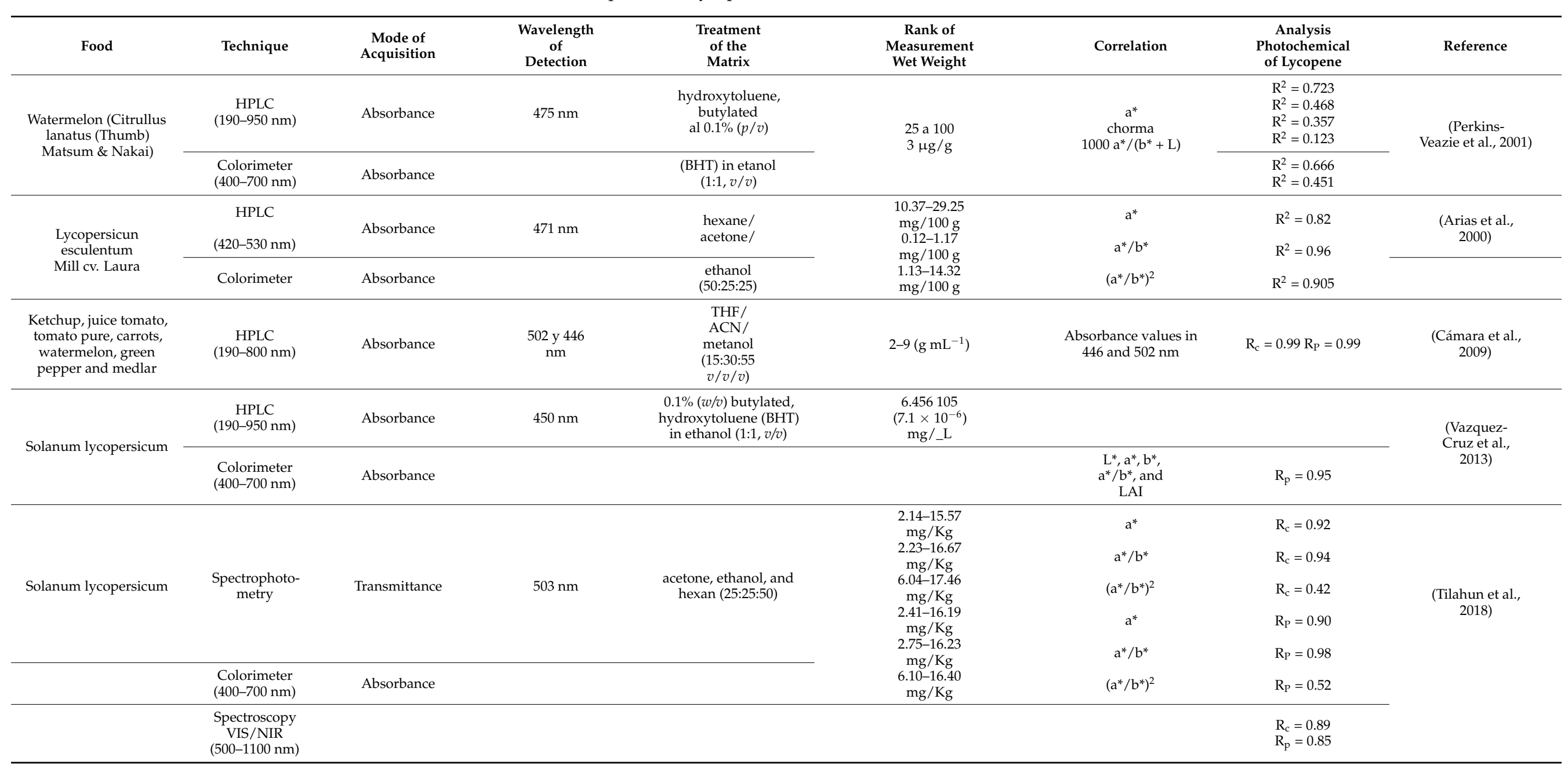


Table 4. Cont.

\begin{tabular}{|c|c|c|c|c|c|c|c|c|}
\hline Food & Technique & $\begin{array}{l}\text { Mode of } \\
\text { Acquisition }\end{array}$ & $\begin{array}{c}\text { Wavelength } \\
\text { of } \\
\text { Detection }\end{array}$ & $\begin{array}{l}\text { Treatment } \\
\text { of the } \\
\text { Matrix }\end{array}$ & $\begin{array}{c}\text { Rank of } \\
\text { Measurement } \\
\text { Wet Weight }\end{array}$ & Correlation & $\begin{array}{c}\text { Analysis } \\
\text { Photochemical } \\
\text { of Lycopene }\end{array}$ & Reference \\
\hline \multirow[t]{2}{*}{$\begin{array}{c}\text { Watermelon Citrullus } \\
\text { lanatus }\end{array}$} & $\begin{array}{c}\text { HPLC } \\
(195-650 \mathrm{~nm}) \\
\end{array}$ & Absorbance & $450 \mathrm{~nm}$ & chloroform & $\begin{array}{l}2.65-151.75 \\
(\mathrm{mg} / \mathrm{kg})\end{array}$ & & $\begin{array}{l}R_{c}=0.756 \\
R_{P}=0.805\end{array}$ & $\begin{array}{l}\text { (Tamburini } \\
\text { et al., 2017) }\end{array}$ \\
\hline & $\begin{array}{l}\text { NIR Process } \\
\text { Analyser } \\
900-1700 \mathrm{~nm}\end{array}$ & Reflectance & & & & & & \\
\hline \multirow[t]{2}{*}{ Solanum lycopersicum } & $\begin{array}{c}\text { HPLC } \\
(190-600 \mathrm{~nm})\end{array}$ & Absorbance & $473 \mathrm{~nm}$ & $\begin{array}{c}\text { hexane/acetone/ethanol } \\
(50: 25: 25)\end{array}$ & $\begin{array}{l}144-921 \\
\mathrm{mg} / \mathrm{Kg}\end{array}$ & & $\mathrm{R}_{\mathrm{c}}=0.9996$ & $\begin{array}{l}\text { (Pedro and } \\
\text { Ferreira, } \\
\text { 2005) }\end{array}$ \\
\hline & $\begin{array}{l}\text { Spectrometer } \\
1000-2500 \mathrm{~nm}\end{array}$ & Reflectance & $\begin{array}{c}4000- \\
10,000 \mathrm{~cm}^{-1}\end{array}$ & & & $\begin{array}{c}\text { MSC and } \\
\text { segmentation } \\
\text { of the spectrum } \\
\text { region } 4000 \text { to } 6000 \\
\mathrm{~cm}^{-1} \text { and } 6000 \text { to } 8000 \\
\mathrm{~cm}^{-1}\end{array}$ & & \\
\hline Solanum lycopersicum & $\begin{array}{l}\text { Spectrometer } \\
\text { of pictures } \\
\text { Raman } \\
779-1144 \mathrm{~nm}\end{array}$ & light scattering & $\begin{array}{c}1151 \text { y } 1513 \\
\mathrm{~cm}^{-1}\end{array}$ & chloroform & & & & $\begin{array}{l}\text { (Qin and } \mathrm{Lu}, 2008 \text {; Qin } \\
\text { et al., 2001) }\end{array}$ \\
\hline Solanum lycopersicum & $\begin{array}{l}\text { Spectrograph } \\
396-736 \mathrm{~nm}\end{array}$ & Reflectance & $396-736 \mathrm{~nm}$ & $\begin{array}{l}\text { Nitrogen, Acetone, } \\
\mathrm{CaCO}_{3} \text {, hexane, }(\mathrm{p} / \mathrm{v}) \\
\text { hydroxytoluene, } \\
\text { butylated } \\
\text { (BHT) }\end{array}$ & $\begin{array}{l}7.52-139.0 \\
\mu \mathrm{g} / \mathrm{g}\end{array}$ & Correlation PCA & & $\begin{array}{l}\text { (Polder et al., } \\
\text { 2004) }\end{array}$ \\
\hline \multirow[t]{2}{*}{ Solanum lycopersicum } & $\begin{array}{l}\text { Spectroscopy } \\
\text { VIS/NIR }\end{array}$ & Absorbance & $503 \mathrm{~nm}$ & hexane/ethanol/acetone & & & & $\begin{array}{l}\text { (Liu et al., } \\
2010)\end{array}$ \\
\hline & $\begin{array}{c}\text { Videometer 405, } \\
435,450,470 \\
505,525,570 \\
590,630,645 \\
660,700,780 \\
850,870,890 \\
910,940 \text { and } \\
970 \mathrm{~nm}\end{array}$ & Reflectance & $\begin{array}{l}\text { Video-meter } \\
\text { wave-lengths }\end{array}$ & $\begin{array}{l}\text { (2:1:1), containing } 2.5 \% \\
\text { BHT (butylated } \\
\text { hydroxy toluene) }\end{array}$ & $\begin{array}{l}0.840-36.791 \\
\mathrm{mg} / \mathrm{kg}\end{array}$ & $\begin{array}{l}\text { Neural network with } \\
19 \text { wavelengths }\end{array}$ & $\begin{array}{l}\mathrm{R}_{\mathrm{c}}=0.957 \\
\mathrm{R}_{\mathrm{p}}=0.938\end{array}$ & \\
\hline
\end{tabular}




\section{Discussion}

According to the literature review, it can be noted that in the food industry, different variants of optical systems are used to mathematically describe the lycopene content in fruits. It can be identified that optical systems that measure the lycopene content in fruits use reflectance, absorbance, light scattering, and transmission as a quantitative variable that detects and quantifies this molecule. This is possible because the frequencies used in this measurement are in the infrared, visible, and/or ultraviolet spectrums. Such is the HPLC case, as it uses the optical property of light absorption. Several methods $[1,51,52,55,56,73]$ use this in focus, where the photodiode array detector of the HPLC operates in the range of $450-503 \mathrm{~nm}$. This range is used to identify the maximum absorption peak of this carotenoid. Another proposal is [51], as they reported the use of two absorption peaks with wavelengths of 446 and $502 \mathrm{~nm}$. In many studies, this equipment (HPLC) has achieved extremely reliable results of an $R^{2}=0.99$.

The frequency spectrum usage is an important characteristic to optimize lycopene measurement methods. For example, Perkins et al. [52] used an HPLC with a spectrum between 190 and $950 \mathrm{~nm}$ and in its detection only used the wavelength around $475 \mathrm{~nm}$. Arias et al. [56] worked with HPLC in the spectrum between 420 and $530 \mathrm{~nm}$ and its detection in the wavelength around $471 \mathrm{~nm}$. Cámara et al. [51], Pedro et al. [55], VazquezCruz [1], Tamburini et al. [73], and Tilahun [64] also worked with wide electromagnetic spectrum systems in lycopene detection. It is understood that equipment is designed for quantification at different wavelengths, but by designing equipment in a smaller range, this reduces component costs. Polder et al. [7] used a range of the electromagnetic spectrum between 396-736 nm to recognize lycopene. However, other references make it possible to identify a narrower useful zone between 446 and $503 \mathrm{~nm}$. This allows us to label this space as one range where lycopene can be acknowledged, as shown in Figure 12.

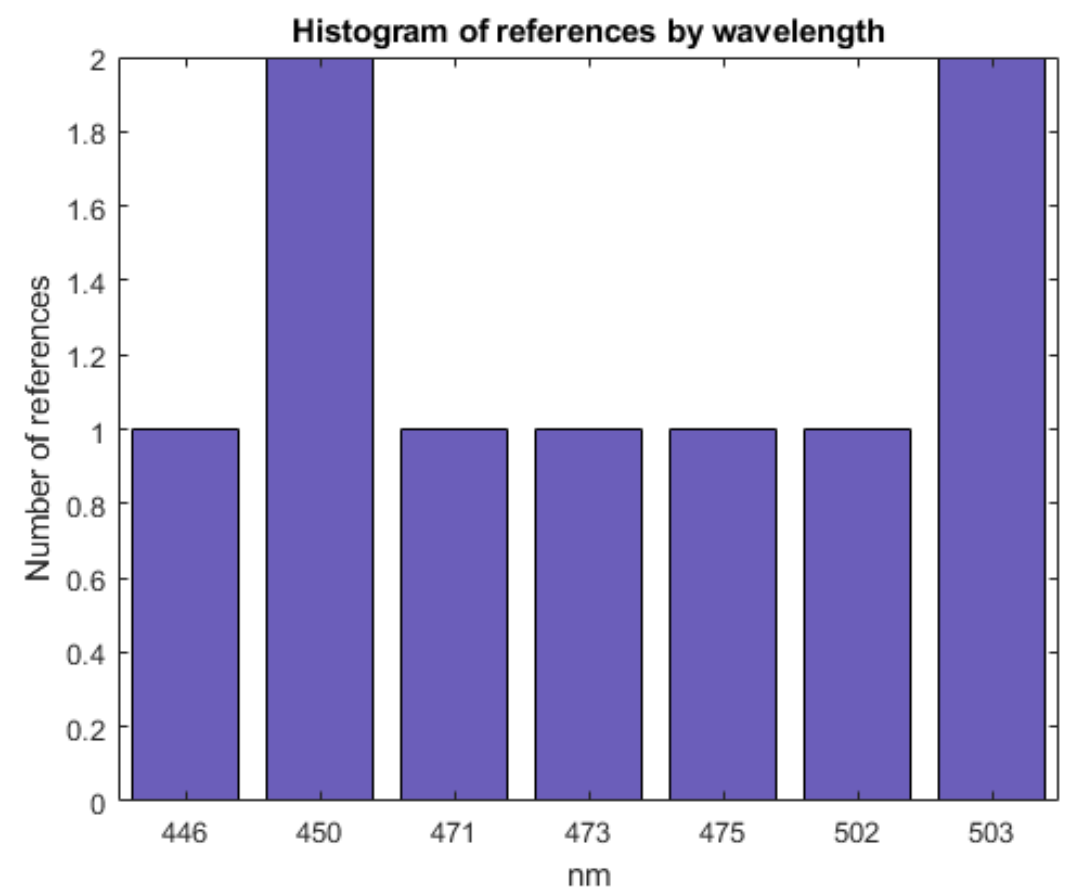

Figure 12. Range of the electromagnetic spectrum most used to detect lycopene.

It was also observed that all current lycopene quantification methods require a standard sample of this molecule to calibrate the equipment $[1,52,56]$. Additionally, several research teams have calibrated the colorimeter using calibrated HPLC to obtain a noninvasive, portable, and fast system for the measurement of lycopene in fruits $[1,53,56]$.

It was also found that there is a limited amount of work on the estimation of lycopene using image processing in the ultraviolet, visible, and infrared spectra [10]. Although 
there are many computer vision works that have analyzed the quality, maturity, and defects of fruits, they have not focused on the lycopene content [2-4,58,64,65,88,89]. Raman spectroscopy has also been scarcely explored to solve this problem due to the cost, size, and controlled working conditions $[84,85,89]$. This could change in the future thanks to advances in technology, as the electronics industry offers us cameras with low cost and sensitivity in the ultraviolet, visible, and near infrared range, as Wu et al. [59] has claimed.

An important phenomenon in the study of the generation and degradation of lycopene in fruits is the effect of UV, VIS, and infrared radiation. Liu et al. [34] is the only study found on this topic.

Another interesting aspect to highlight is the correlation higher than $R^{2}=0.9$ reached by HPLC when the lycopene content in tomato is measured. However, for other fruits, this efficiency drops to $\mathrm{R}^{2}=0.72$.

On the other hand, optical absorption is used in coloration quantification of the fruit epicarp. This measurement is related to the change in lycopene content and is a tool to estimate this important molecule. This descriptor is generally determined by using the $a / b$ quantity in CIE $\mathrm{L}^{*} \mathrm{a}^{*} \mathrm{~b}$ space, which it is the most sensitive factor in identifying measurements from $10.375 \mathrm{mg} / 100 \mathrm{~g}$ wet weight [56] and the $\mathrm{a}^{*}$ component allows measurement of contents of $29.25 \mathrm{mg} / 100 \mathrm{~g}$ wet weight [52]. Between important relations, we note that there is a general increase in reflectance and transmittance in the region of 405 to $780 \mathrm{~nm}[64,73]$. This optical property behavior coincides with the changes in the absorption spectrum reported by [90]. This fact is related to the maturity stage of the fruit and the change in lycopene content.

Although, HPLC continues to be the most reliable equipment (par excellence) to determine the amount of lycopene in fruits. Portable and easy-to-use equipment, such as the colorimeter and artificial vision systems, are beginning to increase in use because they help the agri-food industry to monitor the content of lycopene in fruits from its cultivation to its consumption without destroying the samples. Additionally, its reliability is increasing due to technological tools, such as artificial intelligence, and improvements in sensors, such as low power consumption and resolution.

\section{Conclusions}

The current review provides a description of the techniques used for quantification of lycopene contents in various fruits: High-performance liquid chromatography (HPLC), colorimetry, NIR spectroscopy, UV-Vis spectroscopy, Raman spectroscopy, multispectral images (MSI), and hyperspectral images (HSI). The HPLC and spectrophotometry methods can provide more efficient results, but their measurement procedures are lengthy and complicated. In contrast, both multispectral, hyperspectral, and colorimeter imaging techniques are fast and non-contact, and suitable for online applications but still face many challenges regarding their accuracy. NIR spectroscopy, UV-Vis spectroscopy, and Raman spectroscopy are moderately reliable with respect to HPLC. Likewise, current techniques have certain limitations that restrict their comprehensive applications in industrial food inspections. A solution that several research teams are implementing to measure lycopene content in the field is the calibration of colorimeters with respect to HPLC. Studies that considered this method of determining lycopene contents demonstrated that the use of the CIELAB model facilitates the calculations and provides high reliability, although the original color model of the sensors is the RGB model. A relevant finding is that the efficiency in the lycopene measurement in tomato turns out to be more efficient than in other fruits. This motivates the discovery of techniques to improve the estimation in various fruits that contain lycopene. In general, the introduction of artificial intelligence algorithms, the internet of things, parallel processing hardware, and the reduction of equipment costs are areas of future study that lead to the early translation of laboratory results to field applications. 
Author Contributions: M.-J.V.-A., M.-G.B.-S. and A.-I.B.-G.; methodology, J.-A.P.-M. and J.-E.B.-Á.; validation, A.E.-C.; formal analysis, J.-E.B.-Á. and J.P.-O.; investigation, J.-A.P.-M.; writing-original draft preparation, M.-G.B.-S. and M.-J.V.-A.; writing-review and editing, A.-I.B.-G.; and supervision, A.-I.B.-G. All authors have read and agreed to the published version of the manuscript.

Funding: This research was funded by CONACyT and Tecnológico Nacional de México.

Conflicts of Interest: The authors declare no conflict of interest.

\section{References}

1. Vazquez-Cruz, M.A.; Jimenez-Garcia, S.N.; Luna-Rubio, R.; Contreras-Medina, L.M.; Vazquez-Barrios, E.; Mercado-Silva, E.; Torres-Pacheco, I.; Guevara-Gonzalez, R.G. Application of neural networks to estimate carotenoid content during ripening in tomato fruits (Solanum lycopersicum). Sci. Hortic. 2013, 162, 165-171. [CrossRef]

2. Villaseñor-Aguilar, M.J.; Bravo-Sánchez, M.G.; Padilla-Medina, J.A.; Vázquez-Vera, J.L.; Guevara-González, R.G.; GarcíaRodríguez, F.J.; Barranco-Gutiérrez, A.I. A maturity estimation of bell pepper (Capsicum annuum L.) by artificial vision system for quality control. Appl. Sci. 2020, 10, 5097. [CrossRef]

3. Villaseñor-Aguilar, M.-J.; Botello-Álvarez, J.E.; Pérez-Pinal, F.J.; Cano-Lara, M.; León-Galván, M.F.; Bravo-Sánchez, M.-G. Fuzzy-Classification of the maturity of the tomato using a vision system. J. Sens. 2019, 2019, 3175848. [CrossRef]

4. Santoyo-Mora, M.; Sancen-Plaza, A.; Espinosa-Calderon, A.; Barranco-Gutierrez, A.I.; Prado-Olivarez, J. Nondestructive Quantification of the Ripening Process in Banana (Musa AAB Simmonds) Using Multispectral Imaging. J. Sens. 2019, $2019,6742896$. [CrossRef]

5. Chen, P. Use of optical properties of food materials in quality evaluation and materials sorting. J. Food Process Eng. 1978, 2, 307-322. [CrossRef]

6. Birth, G.S. How light interacts with foods. In Quality Detection in Foods; Gaffney, J.J., Ed.; American Society of Agricultural and Biological Engineers: St. Joseph, MI, USA, 1976; Volume 6.

7. Polder, G.; Van Der Heijden, G.W.A.M.; Van der Voet, H.; Young, I.T. Measuring surface distribution of carotenes and chlorophyll in ripening tomatoes using imaging spectrometry. Postharvest Biol. Technol. 2004, 34, 117-129. [CrossRef]

8. Jahns, P.; Holzwarth, A.R. The role of the xanthophyll cycle and of lutein in photoprotection of photosystem II. Biochim. Biophys. Acta BBA Bioenerg. 2012, 1817, 182-193. [CrossRef] [PubMed]

9. Liu, C.; Liu, W.; Chen, W.; Yang, J.; Zheng, L. Feasibility in multispectral imaging for predicting the content of bioactive compounds in intact tomato fruit. Food Chem. 2015, 173, 482-488. [CrossRef]

10. Liu, H.; Mao, J.; Yan, S.; Yu, Y.; Xie, L.; Hu, J.G.; Li, T.; Abbasi, A.M.; Guo, X.; Liu, R.H. Evaluation of carotenoid biosynthesis, accumulation and antioxidant activities in sweetcorn (Zea mays L.) during kernel development. Int. J. Food Sci. Technol. 2010, 53, 381-388. [CrossRef]

11. Quinlan, R.F.; Shumskaya, M.; Bradbury, L.M.T.; Beltrán, J.; Ma, C.; Kennelly, E.J.; Wurtzel, E.T. Synergistic interactions between carotene ring hydroxylases drive lutein formation in plant carotenoid biosynthesis. Plant Physiol. 2012, 160, 204-214. [CrossRef] [PubMed]

12. Walter, M.H.; Floss, D.S.; Strack, D. Apocarotenoids: Hormones, mycorrhizal metabolites and aroma volatiles. Planta 2010, 232, 1-17. [CrossRef] [PubMed]

13. Bonet, M.L.; Canas, J.A.; Ribot, J.; Palou, A. Carotenoids and their conversion products in the control of adipocyte function, adiposity and obesity. Arch. Biochem. Biophys. 2015, 572, 112-125. [CrossRef] [PubMed]

14. Bohn, T.; Desmarchelier, C.; Dragsted, L.O.; Nielsen, C.S.; Stahl, W.; Rühl, R.; Keijer, J.; Borel, P. Host-related factors explaining interindividual variability of carotenoid bioavailability and tissue concentrations in humans. Mol. Nutr. Food Res. 2017, 61, 1600685. [CrossRef]

15. Pan, W.H.; Yeh, N.H.; Yang, R.Y.; Lin, W.H.; Wu, W.C.; Yeh, W.T.; Sung, M.-K.; Lee, H.-S.; Chang, S.-J.; Huang, C.-J.; et al. Vegetable, fruit, and phytonutrient consumption patterns in Taiwan. J. Food Drug Anal. 2016, 25, e1-e12. [CrossRef] [PubMed]

16. Rao, A.V.; Agarwal, S. Role of lycopene as antioxidant carotenoid in the prevention of chronic diseases: A review. Nutr. Res. 1999, 19, 305-323. [CrossRef]

17. Global Carotenoids Market—Premium Insight, Competitive News Feed Analysis, Company Usability Profiles, Market Sizing \& Forecasts to 2025. Available online: https:/ / www.marketresearch.com/360iResearch-v4164/Global-Carotenoids-PremiumInsight-Competitive-13036149/ (accessed on 15 June 2021).

18. Desmarchelier, C.; Bore, P. Overview of carotenoid bioavailability determinants: From dietary factors to host genetic variations. Trends Food Sci. Technol. 2017, 69, 270-280. [CrossRef]

19. Rao, A.V.; Shen, H. Effect of low dose lycopene intake on lycopene bioavailability and oxidative stress. Nutr. Res. 2002, 22, 1125-1131. [CrossRef]

20. Rao, A.V.; Ray, M.R.; Rao, L.G. Lycopene. Adv. Food Nutr. Res. 2006, 51, 99-164. [PubMed]

21. Rao, A.V.; Rao, L.G. Carotenoids and human health. Pharmacol. Res. 2007, 55, 207-216. [CrossRef] [PubMed]

22. Chauhan1, K.; Sharma, S.; Agarwal, N.; Chauhan, B. Lycopene of tomato fame: Its role in health and disease. Int. J. Pharm. Sci. Rev. Res. 2011, 10, 99-115. 
23. Durairajanayagam, D.; Agarwal, A.; Ong, C.; Prashast, P. Lycopene and male infertility. Asian J. Androl. $2014,16,420-425$. [PubMed]

24. Mezzomo, N.; Ferreira, S.R.S. Carotenoids Functionality, Sources, and Processing by Supercritical Technology: A Review. J. Chem. 2016, 2016, 3164312. [CrossRef]

25. Hashimoto, H.; Uragami, C.; Cogdell, R.J. Carotenoids and Photosynthesis. In Carotenoids in Nature; Stange, C., Ed.; Springer: Cham, Switzerland, 2016; pp. 111-139.

26. Ermakov, I.V.; Gellermann, W. Optical detection methods for carotenoids in human skin. Arch. Biochem. Biophys. 2015, 572, 101-111. [CrossRef] [PubMed]

27. Whigham, L.D.; Redelfs, A.H. Optical detection of carotenoids in living tissue as a measure of fruit and vegetable intake. In 2015 37th Annual International Conference of the IEEE Engineering in Medicine and Biology Society (EMBC); IEEE: Piscataway, NJ, USA, 2015; pp. 8197-8200.

28. Brecht, J.K.; Saltveit, M.E.; Talcott, S.T.; Schneider, K.R.; Felkey, K.; Bartz, J.A. Fresh-cut vegetables and fruits. Hortic. Rev. Am. Soc. Hortic. Sci. 2004, 30, 185-251.

29. Khudairi, A.K.; Arboleda, O.P. Phytochrome-mediated Carotenoid Biosynthesis and Its Influence by Plant Hormones. Physiol. Plant. 1971, 24, 18-22. [CrossRef]

30. Ronnie, L.T.; Jen, J.J. Phytochrome-mediated Carotenoids Biosynthesis in Ripening Tomatoes. Plant Physiol. $1975,56,452-453$.

31. Barrett, D.M.; Anthon, G.E. Color Quality of Tomato Products. In Color Quality of Fresh and Processed Foods; Culver, C.A., Wrolstad, R.E., Eds.; American Chemical Society: Washington, DC, USA, 2008; pp. 131-139.

32. Meléndez-Martínez, A.J.; Britton, G.; Vicario, I.M.; Heredia, F.J. Relationship between the colour and the chemical structure of carotenoid pigments. Food Chem. 2007, 101, 1145-1150. [CrossRef]

33. Periago, M.J.; Martinez-Valverde, I.; Ros, G. Propiedades químicas, biológicas y valor nutritivo del licopeno. An. Vet. 2001, 66, $51-66$.

34. Liu, L.H.; Zabaras, D.; Bennett, L.E.; Aguas, P.; Woonton, B.W. Effects of UV-C, red light and sun light on the carotenoid content and physical qualities of tomatoes during post-harvest storage. Food Chem. 2009, 115, 495-500. [CrossRef]

35. Zielinska, M.A.; Wesołowska, A.; Pawlus, B.; Hamułka, J. Health Effects of Carotenoids during Pregnancy and Lactation. Nutrients 2017, 9, 838. [CrossRef]

36. Bhat, R.; Ameran, S.B.; Voon, H.C.; Karim, A.A.; MinTze, L. Quality attributes of starfruit (Averrhoa carambola L.) juice treated with ultraviolet radiation. Food Chem. 2011, 127, 641-644. [CrossRef] [PubMed]

37. Agilent Technologies. Agilent 1200 Infinity Series Diode Array Detectors User Manual. 2015. Available online: https://www. agilent.com/cs/library/usermanuals/public/G4212-90013_DAD-A-B_USR_EN.pdf (accessed on 17 July 2021).

38. Dumas, Y.; Dadomo, M.; Di Lucca, G.; Grolier, P. Effects of environmental factors and agricultural techniques on antioxidantcontent of tomatoes. J. Sci. Food Agric. 2003, 83, 369-382. [CrossRef]

39. Ilić, Z.S.; Fallik, E. Light quality manipulation improves vegetable quality at harvest and postharvest: A review. Environ. Exp. Bot. 2017, 139, 79-90. [CrossRef]

40. Burns, J.; Fraser, P.D.; Bramley, P.M. Identification and quantification of carotenoids, tocopherols and chlorophylls in commonly consumed fruits and vegetables. Phytochemistry 2003, 62, 939-947. [CrossRef]

41. Pesek, A.; Warthesen, J.J. Photodegradation of carotenoids in a vegetable juice system. J. Food Sci. 1987, 52, 744-746. [CrossRef]

42. Lee, M.T.; Chen, B.H. Stability of lycopene during heating and illumination in a model system. Food Chem. 2002, 78, 425-432. [CrossRef]

43. Steffen, H.; Zumstein, P.; Rice, R.G. Fruit and Vegetables Disinfection at SAMRO, Ltd. Using Hygienic Packaging by Means of Ozone and UV Radiation. Ozone Sci. Eng. 2010, 32, 144-149. [CrossRef]

44. Stevens, C.; Khan, V.A.; Wilson, C.L.; Lua, J.Y.; Chalutz, E.; Drobyc, S. The effect of fruit orientation of postharvest commodities following low dose ultraviolet light-C treatment on host induced resistance to decay. Crop Prot. 2005, 24, 756-759. [CrossRef]

45. Bhat, R. Impact of ultraviolet radiation treatments on the quality of freshly prepared tomato (Solanum lycopersicum) juice. Food Chem. 2016, 213, 635-640. [CrossRef] [PubMed]

46. Noga, L.; Noga, G.; Fiebig, A.; Hunsche, M. Effects of continuous red light and short daily UV exposure during postharvest on carotenoid concentration and antioxidant capacity in stored tomatoes. Sci. Hortic. 2017, 226, 97-103.

47. Kumar, M.; Ahuja, S.; Dahuja, A.; Kumar, R.; Singh, B. Gamma radiation protects fruit quality in tomato by inhibiting the production of reactive oxygen species (ROS) and ethylene. J. Radioanal. Nucl. Chem. 2014, 301, 871-880. [CrossRef]

48. Silva-Sena, G.; de Santana, E.N.; Nascimento, R.G.E.; Neto, J.O.; de Oliveira, C.A.; de Figueiredo, S.G. Effect of Gamma Irradiation on Carotenoids and Vitamin C Contents of Papaya Fruit (Carica papaya L.) Cv. Golden. Food Process. Technol. 2014, , 337-339.

49. Artal, P.; Schwiegerling, J.; Schwiegerling, J. Handbook of Visual Optics. Handb. Vis. Opt. 2017, 1, 449-450.

50. Skoog, D.A.; Holler, F.J.; Nieman, T.A. Principios de Análisis Instrumental; McGraw-Hill Interamericana de España: Madrid, Spain, 2001.

51. Cámara, M.; Torrecilla, J.S.; Caceres, J.O.; Mata, M.C.S.; Fernández-Ruiz, V. Neural Network Analysis of Spectroscopic Data of Lycopene and $\$ \beta \$$-Carotene Content in Food Samples Compared to HPLC-UV-Vis. J. Agric. Food Chem. 2009, 58, 72-75. [CrossRef]

52. Perkins-Veazie, P.; Collins, J.K.; Pair, S.D.; Roberts, W. Lycopene content differs among red-fleshed watermelon cultivar. J. Sci. Food Agric. 2001, 81, 983-987. [CrossRef] 
53. Sadler, G.; Dezman, J.D.D. Rapid extraction of lycopene and $\beta$-carotene from reconstituted tomato paste and pink grapefruit homogenates. J. Food Sci. 1990, 55, 1460-1461. [CrossRef]

54. Barba, A.I.O.; Hurtado, M.C.; Mata, M.C.S.; Ruiz, V.F.; Tejada, M.L.S. De Application of a UV-vis detection-HPLC method for a rapid determination of lycopene and $\$ \beta \$$-carotene in vegetables. Food Chem. 2006, 95, 328-336. [CrossRef]

55. Pedro, A.M.K.; Ferreira, M.M. Nondestructive determination of solids and carotenoids in tomato products by near-infrared spectroscopy and multivariate calibration. ACS Publ. 2005, 77, 2505-2511. [CrossRef]

56. Arias, R.; Lee, T.-C.; Logendra, L.; Janes, H. Correlation of lycopene measured by HPLC with the $\mathrm{L}^{*}, \mathrm{a}^{*}, \mathrm{~b}^{*}$ color readings of a hydroponic tomato and the relationship of maturity with color and lycopene content. J. Agric. Food Chem. 2000, 48, 1697-1702. [CrossRef]

57. Li, B.; Lecourt, J.; Bishop, G. Advances in Non-Destructive Early Assessment of Fruit Ripeness towards Defining Optimal Time of Harvest and Yield Prediction-A Review. Plants 2018, 7, 3. [CrossRef]

58. Mendoza, F.; Aguilera, J.M. Application of image analysis for classification of ripening bananas. J. Food Sci. 2004, 69. [CrossRef]

59. Wu, D.; Sun, D.-W. Colour measurements by computer vision for food quality control-A review. Trends Food Sci. Technol. 2013, 29,5-20. [CrossRef]

60. Camelo, A.F.L.; Gómez, P.A. Comparison of color indexes for tomato ripening. Hortic. Bras. 2004, 22, 534-537. [CrossRef]

61. Hobson, G.E.; Adams, P.; Dixon, T.J. Assessing the colour of tomato fruit during ripening. J. Sci. Food Agric. 1983, 34, $286-292$. [CrossRef]

62. Wyszecki, G.; Stiles, W.S. Color Science; Wiley: New York, NY, USA, 1982.

63. Bleys, J. Language Strategies for the Domain of Colour; Language Science Press, 2016.

64. Va Roy, J.; Keresztes, J.C.; Wouters, N.; De Ketelaere, B.; Saeys, W. Measuring colour of vine tomatoes using hyperspectral imaging. Postharvest Biol. Technol. 2017, 129, 79-89. [CrossRef]

65. Ye, X.; Izawa, T.; Zhang, S. Rapid determination of lycopene content and fruit grading in tomatoes using a smart device camera. Cogent Eng. 2018, 5, 1504499. [CrossRef]

66. Tilahun, S.; Park, D.S.; Seo, M.H.; Hwang, I.G.; Kim, S.H.; Choi, H.R.; Jeong, C.S. Prediction of lycopene and $\$ \beta \$$-carotene in tomatoes by portable chroma-meter and VIS/NIR spectra. Postharvest Biol. Technol. 2018, 136, 50-56. [CrossRef]

67. Huang, Y.; Lu, L.R.; Kunjie, C. Prediction of firmness parameters of tomatoes by portable visible and near-infrared spectroscopy. J. Food Eng. 2018, 222, 185-1984. [CrossRef]

68. Reich, G. Near-infrared spectroscopy and imaging: Basic principles and pharmaceutical applications. Adv. Drug Deliv. Rev. 2005, 57, 1109-1143. [CrossRef]

69. Nicola, B.M.; Beullens, K.; Bobelyn, E.; Peirs, A.; Saeys, W.; Theron, K.I.; Lammertyn, J. Nondestructive measurement of fruit and vegetable quality by means of NIR spectroscopy: A review. Postharvest Biol. Technol. 2007, 46, 99-118. [CrossRef]

70. Pan, L.; Lu, R.; Zhu, Q.; McGrath, J.M.; Tu, K. Measurement of moisture, soluble solids, sucrose content and mechanical properties in sugar beet using portable visible and near-infrared spectroscopy. Postharvest Biol. Technol. 2015, 102, 42-50. [CrossRef]

71. Parker, R.S.; Swanson, J.E.; You, C.S.; Edwards, A.J.; Huang, T. Bioavailability of carotenoids in human subjects. Proc. Nutr. Soc. 1999, 58, 155-162. [CrossRef] [PubMed]

72. Xie, L.; Ying, Y. Use of near-infrared spectroscopy and least-squares support vector machine to determine quality change of tomato juice. J. Zhejiang Univ. Sci. B 2009, 10, 465-471. [CrossRef] [PubMed]

73. Tamburini, E.; Costa, S.; Rugiero, I.; Pedrini, P.; Marchetti, M.G. Quantification of Lycopene, Beta-Carotene, and Total Soluble Solids in Intact Red-Flesh Watermelon (Citrullus lanatus) Using On-Line Near-Infrared Spectroscopy. Sensors 2017, 17, 746. [CrossRef] [PubMed]

74. Eliasson, C.; Matousek, P. Noninvasive Authentication of Pharmaceutical Products through Packaging Using Spatially Offset Raman Spectroscopy. Anal. Chem. 2007, 79, 1696-1701. [CrossRef] [PubMed]

75. Ellis, D.I.; Brewster, V.L.; Dunn, W.B.; Allwood, J.W.; Golovanov, A.P.; Goodacre, R. Fingerprinting food: Current technologies for the detection of food adulteration and contamination. Chem. Soc. Rev. 2012, 41, 5706-5727. [CrossRef]

76. Tao, F.; Ngadi, M. Applications of spectroscopic techniques for fat and fatty acids analysis of dairy foods. Curr. Opin. Food Sci. 2017, 17, 100-112. [CrossRef]

77. Hoskins, L.C. Resonance Raman spectroscopy of beta-carotene and lycopene, a physical chemistry experiment. J. Chem. Educ. 1984, 61, 4608. [CrossRef]

78. Baranska, M.; Schulz, H.; Nothnagel, T. Tissue-specific accumulation of carotenoids in carrot roots. Planta 2006, 224, 1028-1037. [CrossRef]

79. da Silva, C.E.; Vandenabeele, P.; Edwards, H.G.M.; de Oliveira, L.F.C. Raman spectra of carotenoids in natural products. Anal. Bioanal. Chem. 2008, 392, 1489-1496. [CrossRef] [PubMed]

80. de Oliveira, V.E.; Castro, H.V.; Edwards, H.G.M.; de Oliveira, L.F.C. Carotenes and carotenoids in natural biological samples: A Raman spectroscopic analys. J. Raman Spectrosc. 2010, 41, 642-650. [CrossRef]

81. Merlin, J.C. Resonance Raman spectroscopy of carotenoids and carotenoid-containing systems. Pure Appl. Chem. 1985, 57, 785-792. [CrossRef]

82. Schulz, H.; Baranska, M. Identification and quantification of valuable plant substances by IR and Raman spectroscopy. Vib. Spectrosc. 2007, 43, 13-25. [CrossRef] 
83. Withnall, R.; Chowdhry, B.Z.; Silver, J.; Edwards, H.G.M.; de Oliveira, L.F.C. Raman spectra of carotenoids in natural products. Spectrochim. Acta Part A Mol. Biomol. Spectrosc. 2003, 59, 2207-2212. [CrossRef]

84. Trebolazabala, J.; Maguregui, M.; Morillas, H.; de Diego, A.; Madariaga, J.M. Portable Raman spectroscopy for an in-situ monitoring the ripening of tomato (Solanum lycopersicum) fruits. Spectrochim. Acta Part A Mol. Biomol. Spectrosc. 2017, 180, 138-143. [CrossRef] [PubMed]

85. Qin, J.; Chao, K.; Kim, M.S. Evaluating carotenoid changes in tomatoes during postharvest ripening using Raman chemical imaging. In Sensing for Agriculture and Food Quality and Safety III; IEEE: Piscataway, NJ, USA, 2011; Volume 8027, p. 802703.

86. Lieber, C.A.; Mahadevan-Jansen, A. Automated Method for Subtraction of Fluorescence from Biological Raman Spectra. Appl. Spectrosc. 2003, 57, 1363-1367. [CrossRef]

87. Qin, J.; Kim, M.S.; Chao, K.; Chan, D.E.; Delwiche, S.R.; Cho, B.-K. Line-scan hyperspectral imaging techniques for food safety and quality applications. Appl. Sci. 2017, 7, 125. [CrossRef]

88. Qin, J.; Lu, R. Measurement of the optical properties of fruits and vegetables using spatially resolved hyperspectral diffuse reflectance imaging technique. Postharvest Biol. Technol. 2008, 49, 355-365. [CrossRef]

89. Gastélum-Barrios, A.; García-Trejo, J.F.; Macías-bobadilla, G.; Toledano-Ayala, M. Portable System to Estimate Ripeness and Lycopene Content in Fresh Tomatoes Based on Image Processing. In 2018 XIV International Engineering Congress (CONIIN); IEEE: Piscataway, NJ, USA, 2018.

90. Qin, J.; Chao, K.; Kim, M.S. Investigation of Raman chemical imaging for detection of lycopene changes in tomatoes during postharvest ripening. J. Food Eng. 2011, 107, 277-288. [CrossRef] 